\title{
Physiology and Plasticity of Morphologically Identified Cells in the Mormyrid Electrosensory Lobe
}

\author{
Curtis C. Bell, ${ }^{1}$ Angel Caputi, ${ }^{2}$ and Kirsty Grant ${ }^{3}$ \\ ${ }^{1}$ R. S. Dow Neurological Sciences Institute, Legacy Good Samaritan Hospital and Medical Center, Portland, Oregon \\ 97209, 2Division de Neuroanatomia Comparada, Instituto de Investigaciones Biologicas Clemente Estable, Montevideo, \\ 11600 Uruguay, and 3/nstitut Alfred Fessard, Centre National de la Recherche Scientifique, 91190 Gif sur Yvette, France
}

The electrosensory lobe (ELL) of mormyrid electric fish is the first stage in the central processing of sensory input from electroreceptors. The responses of cells in ELL to electrosensory input are strongly affected by corollary discharge signals associated with the motor command that drives the electric organ discharge (EOD). This study used intracellular recording and staining to describe the physiology of three major cell types in the mormyrid ELL: the medium ganglion cell, the large ganglion cell, and the large fusiform cell. The medium ganglion cell is a Purkinje-like interneuron, whereas the large ganglion and large fusiform cells are efferent neurons that convey electrosensory information to higher stages of the system.

Clear differences were observed among the three cell types. Medium ganglion cells showed two types of spikes, a small narrow spike and a large broad spike that were probably of axonal and dendro-somatic origin, respectively, whereas the large ganglion and large fusiform cells showed only large narrow spikes. Most of the medium ganglion cells and all of the large ganglion cells were inhibited by electrosensory stimuli in the center of their receptive fields, whereas the large fusiform cells were excited by such stimuli.

Responses to the EOD corollary discharge were different in the three cell types, and these responses underwent plastic changes after a few minutes of pairing with an electrosensory stimulus. Plastic changes were also observed in medium and large ganglion cells after the corollary discharge was paired with depolarizing, intracellular current pulses.

Key words: mormyrid; electric fish; electrosensory; cerebellum; plasticity; corollary discharge; efference copy
Primary afferent input from electroreceptors, from hair cells of the mechanical lateral line system, and from hair cells of the eighth nerve end organs terminates within cerebellum-like structures in fish. These structures integrate peripheral input with descending input from central sources. The central inputs convey various types of information, such as corollary discharge signals associated with motor commands, proprioceptive signals indicating body positions, and recurrent feedback signals from higher central stages to which the cerebellum-like structures project (Montgomery et al., 1995).

The central or "descending" inputs exert various effects, including the gating of (re)afferent (von Holst and Mittelstaedt, 1950) sensory input by corollary discharge signals associated with motor commands (Bell, 1989), and gain control by feedback from higher stages of the same sensory system (Bastian, 1986). Some of the descending effects are plastic and depend on previous associations with peripheral sensory input (Bell, 1981; Montgomery and Bodznick, 1994; Bastian, 1995). A few minutes of association between peripheral and central inputs results in the central input eliciting a negative image of the previously paired sensory input. Thus, the central input acts as a predictor of expected sensory input. Addition of the negative image of predicted input to the

Received Dec. 12, 1996; revised May 22, 1997; accepted May 28, 1997.

This study was supported by a grant from the National Science Foundation (C.C.B.), by a Fogarty International Fellowship from National Institutes of Health (A.C.), and by funds from the Centre National de la Recherche Scientifique of France (K.G.). We thank Dr. Charles Russell for a critical reading of this manuscript.

Correspondence should be addressed to Curtis Bell, R. S. Dow Neurological Sciences Institute, 1120 Northwest 20th Avenue, Portland, OR 97210.

Copyright (C) 1997 Society for Neuroscience $0270-6474 / 97 / 176409-15 \$ 05.00 / 0$ actual input removes predictable features, allowing unpredictable features to stand out more clearly.

This study focuses on the cerebellum-like electrosensory lobe (ELL) of mormyrid electric fish where the primary afferent fibers from electroreceptors terminate and more specifically in the regions of ELL that receive input from mormyromast electroreceptors (Fig. 1). These electroreceptors are responsible for active electrolocation, in which the fish senses external objects by their effect on the pattern of transcutaneous current flow generated by the fish's own electric organ discharge (EOD). Afferents from mormyromast electroreceptors project to the medial and dorsolateral zones of ELL (see Fig. 1, $M Z$ and $D L Z$ ) (Bell et al., 1989).

Corollary discharge signals associated with the motor command that elicits the EOD are prominent in the mormyrid ELL (Zipser and Bennett, 1976; Bell and Grant, 1992). Thus, the ELL is strongly affected at each EOD by EOD-evoked afferent input and by corollary signals associated with the EOD motor command. Some corollary discharge effects are fixed, but others are plastic and depend on the sensory input that has followed the EOD in the recent past (Bell, 1982; Bell and Grant, 1992).

Previous studies of the mormyromast ELL used extracellular recordings of field potentials and single cell activity to characterize the responses to electrosensory stimuli and to the electric organ corollary discharge (Bell and Grant, 1992; Bell et al., 1992). The present study extends the previous work with intracellular recording and staining to further characterize the cells and to identify them morphologically. Three major cell types were examined: medium ganglion cells, large ganglion cells, and large fusiform cells (Grant et al., 1996; Meek et al., 1996). The large ganglion and large fusiform cells are glutamatergic efferent cells, 


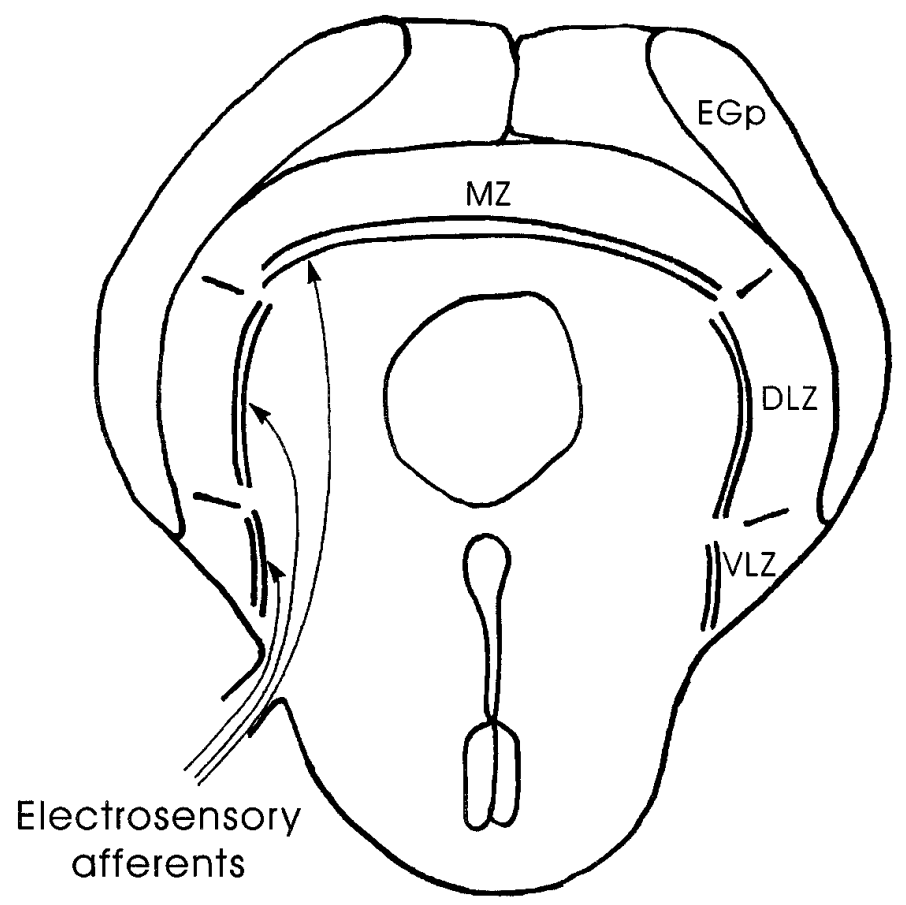

Figure 1. Schematic diagram of a frontal section through ELL. The ELL is divided into medial $(M Z)$, dorsolateral $(D L Z)$, and ventrolateral $(V L Z)$ zones. Much of ELL is covered by the eminentia granularis posterior $(E G p)$, which contains the granule cells that give rise to the parallel fibers of ELL molecular layer.

whereas the medium ganglion cells are GABAergic Purkinje-like interneurons that probably terminate on the efferent cells and on other medium ganglion cells (Fig. 2).

\section{MATERIALS AND METHODS}

General. A total of 31 mormyrid fish of the species Gnathonemus petersii were used in these experiments. The fish ranged from 12 to $15 \mathrm{~cm}$ in length. Surgery to expose the brain was performed under anesthesia, and curare was given after the surgery. The EOD motor command that would elicit an EOD in the noncurarized fish continues to be emitted spontaneously under curare at rates of $2-4 / \mathrm{sec}$ but without the normally consequent EOD. Responses of cells in the ELL to this motor command alone are considered corollary discharge responses. The curare made it possible to examine the corollary discharge responses in isolation from the normally consequent EOD and to maintain the electrosensory input under experimental control.

Cells in ELL were recorded intracellularly with sharp microelectrodes containing biocytin. Responses to electrosensory stimuli were examined by delivering brief current pulses through bipolar stimulating electrodes held close to the skin within the receptive field of the cells. Responses to the corollary discharge signals were examined as well as the effect of the corollary discharge input on electrosensory responses. The latter were tested by delivering electrosensory stimuli at various delays in relation to the EOD motor command. Corollary discharge plasticity was tested by delivering electrosensory stimuli or intracellular current pulses at fixed delays with respect to the motor command and maintaining such pairing for 1-5 min. Corollary discharge responses after the pairing were compared with responses obtained before the pairing. Antidromic stimulating electrodes were placed in the lateral lemniscus at the level of the mesencephalon in some experiments to determine whether recorded cells were efferent cells. (Efferent axons from ELL reach the mesencephalon by way of the lateral lemniscus.) Intracellular current was passed into the cells to inject biocytin and stain them after their physiological characterization.

The specific methods used in this study are described only briefly here. More detailed information may be found in a previous publication (Bell et al., 1992).

Surgery. Fish were anesthetized with tricaine methanesulfonate (MS-
222; 1:25,000) and held against a wax block with the dorsal part of the head out of the water. A plastic rod was cemented to the anterior part of the skull to hold the head firm. The bone was removed from the caudal part of the skull on one side and the underlying valvula cerebelli was reflected forward to expose the eminentia granularis posterior (EGp). The EGp is a large mass of granule cells that covers most of the lateral and dorsal surfaces of ELL (Fig. 1) and is the source of molecular layer parallel fibers. After surgery, the fish were given curare $(0.1 \mathrm{mg}$, i.m.), and fresh aerated water was passed over the gills for respiration (50 $\mathrm{ml} / \mathrm{min})$.

Recording. The EOD motor command is initiated in the brainstem and is conveyed down the spinal cord to the motoneurons in the tail that innervate the electric organ. The synchronized volley in these motoneurons that would evoke an EOD in the noncurarized fish was recorded with a $\mathrm{Ag}-\mathrm{AgCl}$ disk placed against the skin over the electric organ in the tail (see Fig. 4A, bottom trace). This volley is known as the "command signal". The amplitude of the command signal was between 100 and $200 \mu \mathrm{V}$. The command signal was amplified and fed to a trigger unit that generated a square wave that was then used to trigger the oscilloscope and computer, as well as the stimulator, when electrosensory stimuli were delivered at fixed delays after the command signal. The timing of all command-related events is stated with respect to the first large negative peak of the command signal (see time 0 of the command signal, indicated by an upward arrowhead labeled $T O$ in the bottom trace of Fig. $4 A$ ). The EOD occurs $4.5 \mathrm{msec}$ after this negative peak in the noncurarized fish.

Intracellular recordings were obtained with microelectrodes filled with potassium methyl sulfate $(2 \mathrm{M})$ and biocytin $(2 \%)$. Electrodes were $140-200 \mathrm{M} \Omega$. Biocytin was injected into recorded cells by passing depolarizing intracellular current pulses at $3 \mathrm{~Hz}$ with a duty cycle of $50 \%$ and an amplitude of 1-2 $\mathrm{nA}$ for 2-15 min.

Field potential recordings were made with low-resistance pipettes $(2 \mathrm{M}$ $\mathrm{NaCl} ; 3-10 \mathrm{M} \Omega$ ) to determine the best entry points for subsequent penetrations with high-resistance pipettes. Field potential recording was also used to position the antidromic stimulating electrode in the lateral lemniscus. Antidromic stimulation evokes a characteristic negative wave in the cell layers of ELL (our unpublished observations). The stimulus electrode was placed at a point where this negative wave was evoked with minimal stimulus intensity.

Stimulation. Electrosensory stimuli were delivered to local areas of the skin surface through a pair of chlorided silver balls. The silver balls were $0.5 \mathrm{~mm}$ in diameter, and the poles were $0.5 \mathrm{~cm}$ apart. The axis of the dipole was held roughly perpendicular to the skin during stimulation, with the closest electrode being 1-4 $\mathrm{mm}$ from the skin surface. Stimulus duration was $0.1 \mathrm{msec}$ and intensities were 2-20 $\mu \mathrm{A}$. The electrode closest to the skin was negative. Antidromic stimulation was performed with gold-plated tungsten electrodes (negative current pulses, $0.1 \mathrm{msec}$ in duration and $10-50 \mu \mathrm{A}$ in intensity).

Histology. At the end of the experiment, fish were deeply anesthetized with a concentrated solution of MS-222 $(1: 10,000)$ and perfused through the heart with saline followed by a fixative consisting of $4 \%$ paraformaldehyde in $0.1 \mathrm{~m}$ PBS. The brain was removed and post-fixed for 1-2 d. Vibratome sections were cut and reacted with the ABC reagents from Vector Laboratories (Burlingame, CA) and a modified Hanker-Yates procedure (Hanker et al., 1977; Bell et al., 1981). Sections were mounted on slides and counterstained with Richardson's stain.

\section{RESULTS}

\section{Medium ganglion cells}

Five cells of this type were identified morphologically by biocytin labeling after being studied physiologically (Fig. 3, left column). These cells have a relatively small soma in the superficial part of the ganglion layer, a dense apical dendritic arbor extending throughout the molecular layer, and a single primary basilar dendrite extending from the base of the cell (for a more complete description of the morphology of these cells, see Meek et al., 1996). Golgi studies show two types of medium ganglion cells with basal dendrites in different layers, but these dendrites were not sufficiently well stained in our material to distinguish between these two types. Axonal arbors could be observed in only two of the stained cells and were restricted to the ganglion and plexiform layers in the near neighborhood of the soma. An additional 23 


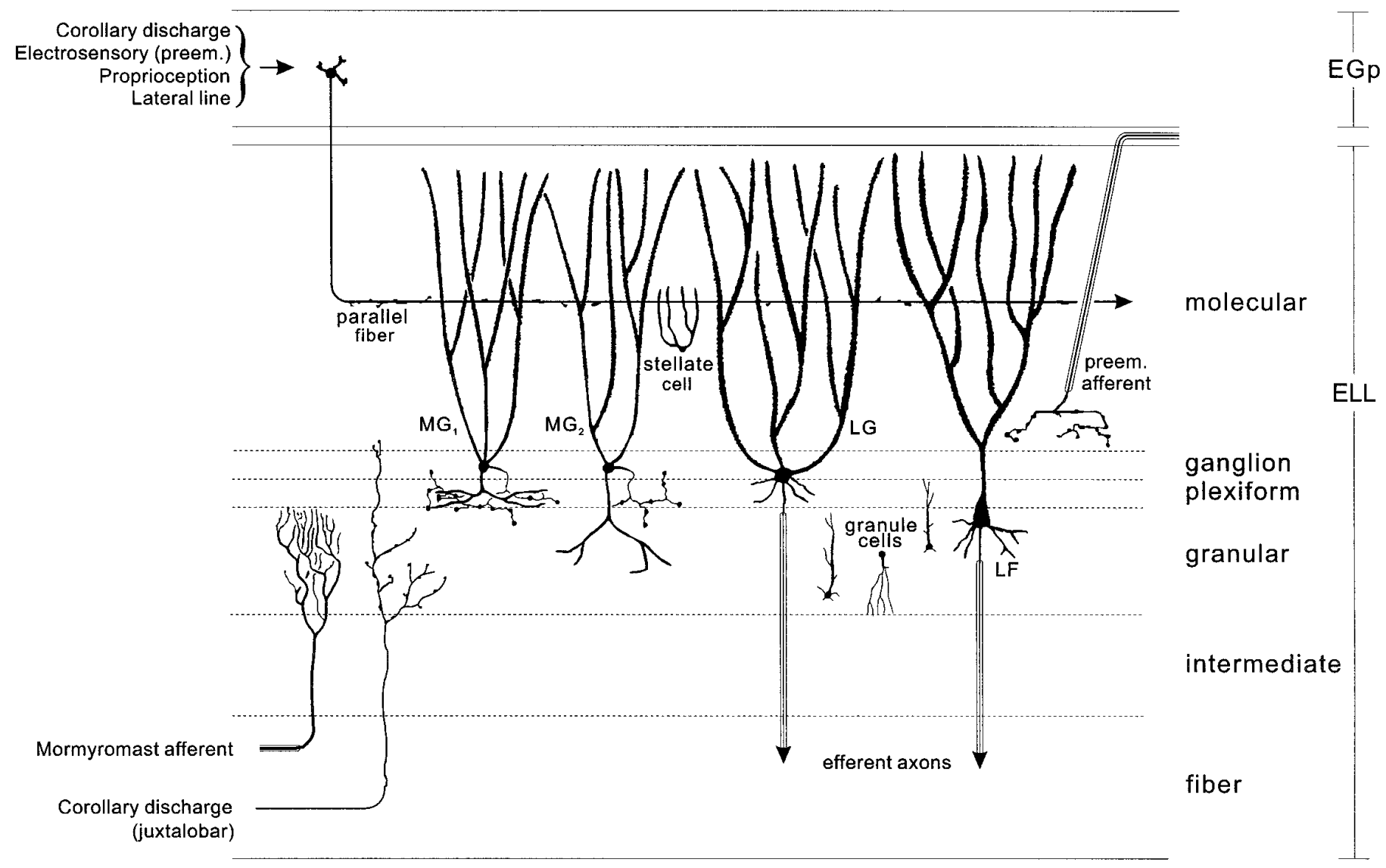

Figure 2. Cell and fiber types of ELL discussed in the text (adapted from Meek, 1993). Primary afferent input terminates in the granular layer (mormyromast afferent). Sensory information is then relayed to different types of interneurons, including two types of medium ganglion cells ( $M G_{I}$ and $\left.M G_{2}\right)$ and efferent projection neurons $(L G$ and $L F)$. The apical dendritic trees of MG, LG, and LF neurons extend through the molecular layer where they are contacted by parallel fibers from EGp. Small stellate cells in the molecular layer are also contacted by the parallel fibers. Parallel fibers convey corollary discharge signals, descending electrosensory information from the preeminential nucleus (preem.), and information from other sensory modalities. The preeminential nucleus also projects directly to the inner molecular layer ( preem. afferent). Corollary discharge input from the juxtalobar nucleus terminates in the granular, plexiform, and ganglion layers. Output neurons of ELL project to the mesencephalon via the lateral lemniscus and give off collaterals to the preeminential nucleus.

cells with similar physiological properties were recorded but not identified morphologically. The physiological similarity is based on the types of spikes recorded intracellularly, the corollary discharge responses of the cells, and the effects of electrosensory stimuli. Recorded membrane potentials of the 33 cells of this type ranged from -70 to $-50 \mathrm{mV}$ (mean, $-60.1 \mathrm{mV}$; SEM, $1.0 \mathrm{mV}$ ).

Two types of spikes were consistently observed in these neurons: a large broad spike, $25-60 \mathrm{mV}$ in amplitude (mean, 49.8 $\mathrm{mV}$; SEM, $1.7 \mathrm{mV} ; n=28$ ) and $10-20 \mathrm{msec}$ in duration (mean, $12.2 \mathrm{msec}$; SEM, $0.4 \mathrm{msec} ; n=28$ ) with a small after hyperpolarization; and a small, narrow spike, 1-10 mV in amplitude (mean, $5.8 \mathrm{mV}$; SEM, $0.4 \mathrm{mV} ; n=27$ ) and $1-2 \mathrm{msec}$ in duration (mean, $1.5 \mathrm{msec}$; SEM, $0.1 \mathrm{msec} ; n=28$ ) (labeled $b$ and $s$, respectively, in Fig. 4). Both types of spikes could be evoked by the corollary discharge-driven EPSP that was characteristic of these cells (Fig. $4 A$; see below) or by intracellular current pulses (Fig. $4 B$ ). The small narrow spike had a lower threshold than the large broad spike, and the large broad spike usually occurred on top of a small narrow spike (as in Fig. $4 A, B$ ). In addition, the large broad spike usually had an inflection on its rising phase (arrowheads in Fig. $4 A, B$ ) that became more pronounced when two broad spikes were evoked in quick succession by two intracellular current pulses (not shown). The inflection reflected the presence of a third type of spike, a medium broad spike, which occasionally occurred in isolation from the large broad spike ( $\mathrm{mb}$ in Fig. $4 A, B)$. A small inflection often occurred on the rising phase of the medium broad spike, reflecting the occurrence of a small narrow spike (Fig. 4B, double arrowhead). The medium broad spike was 8-20 $\mathrm{mV}$ in amplitude and 4-6 msec in duration. Rather broad spikes of 4-8 msec in duration were commonly recorded extracellularly in the molecular layer as the electrode passed through this layer to the deeper cell layers where the intracellular recordings were made. These extracellular spikes had a timing in relation to the corollary discharge that was similar to that of medium ganglion cell broad spikes and could therefore reflect the propagation of broad spikes into the apical dendrites of these cells. Antidromic activation by stimulation of the lateral lemniscus in the mesencephalon was tested in 5 of the 28 cells of this type. No spikes were evoked, a result that is consistent with the identification of these cells as medium ganglion cells, i.e., interneurons.

\section{Corollary discharge responses of medium ganglion cells}

The electric organ corollary discharge (or "corollary discharge") evoked a compound EPSP in these cells with an onset latency of $10-12 \mathrm{msec}$, an amplitude of 3-8 $\mathrm{mV}$, and a duration of $\sim 40 \mathrm{msec}$ (Fig. $4 A$ ). The EPSP consisted of two phases: a brief initial phase 


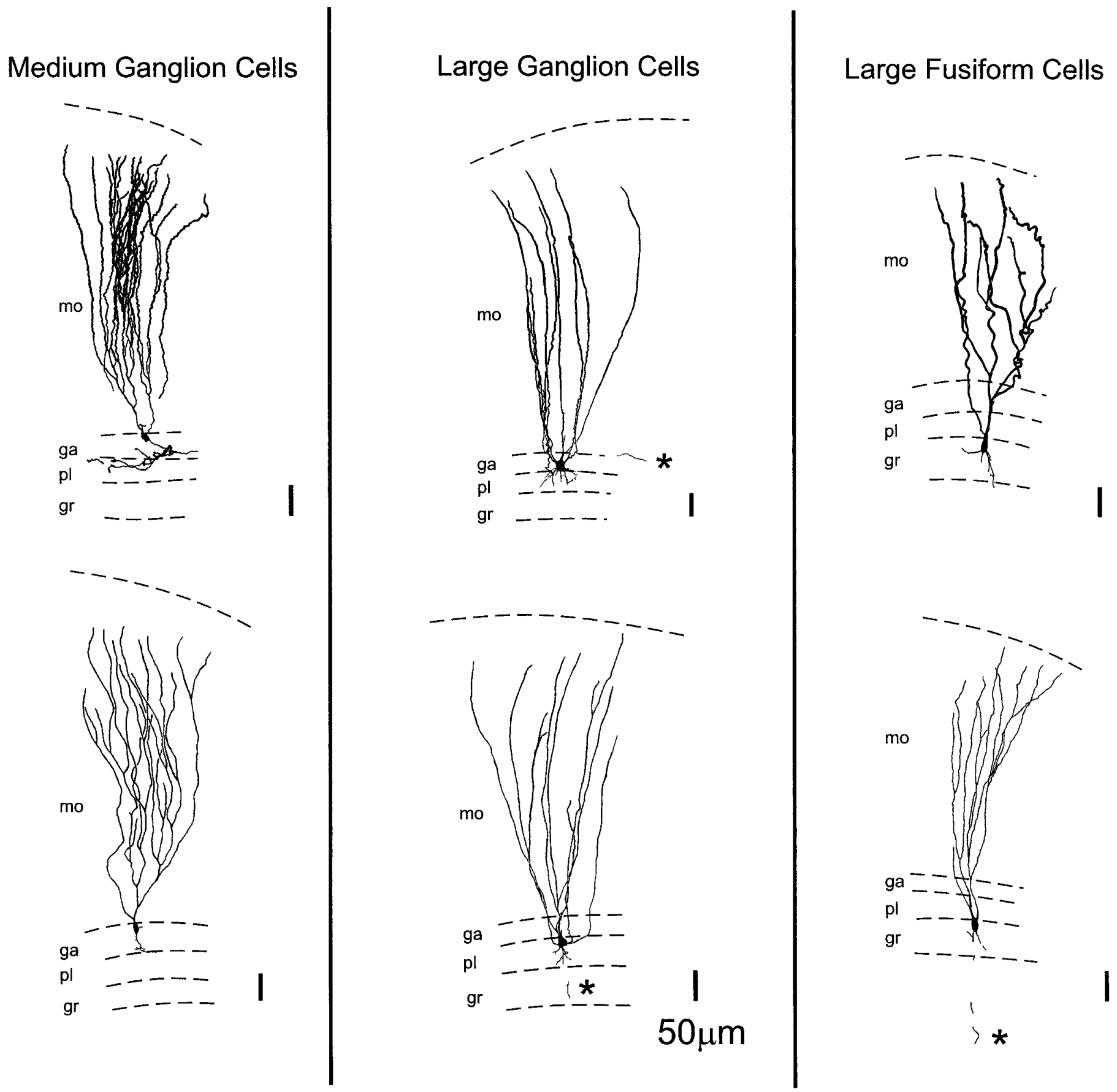

Figure 3. Reconstructions of intracellularly recorded, biocytin-labeled neurons. Left column, Two medium ganglion cells; middle column, large ganglion cells; right column, large fusiform cells. mo, Molecular layer; ga, ganglion layer; $p l$, plexiform layer; gr, granular layer; *, axon. Scale bars, $50 \mu \mathrm{m}$.

with a highly consistent latency and amplitude followed by a longer lasting phase with a more variable amplitude. The initial phase usually elicited a single small spike with a relatively fixed latency, whereas the later phase elicited a brief burst of small spikes with more variable latencies (see raster display of Fig. 4A). Some of these cells showed a brief hyperpolarizing IPSP between the two phases of the EPSP, and some showed a brief hyperpolarizing IPSP just before the corollary discharge EPSP (see Fig. 6, arrows).

\section{Electrosensory responses of medium ganglion cells}

Most of these medium ganglion cells showed an IPSP in response to local electrosensory stimulation at the skin surface (Fig. $5 A$, bottom trace). Twenty-one of the twenty-five cells that responded to electrosensory stimulation showed only an IPSP, one cell showed an IPSP at threshold and a longer latency EPSP at higher intensities, and three cells showed only an EPSP. The IPSPs had minimal latencies of 4-7 msec and were relatively small in amplitude $(1-3 \mathrm{mV})$ when evoked in isolation from the corollary 
A

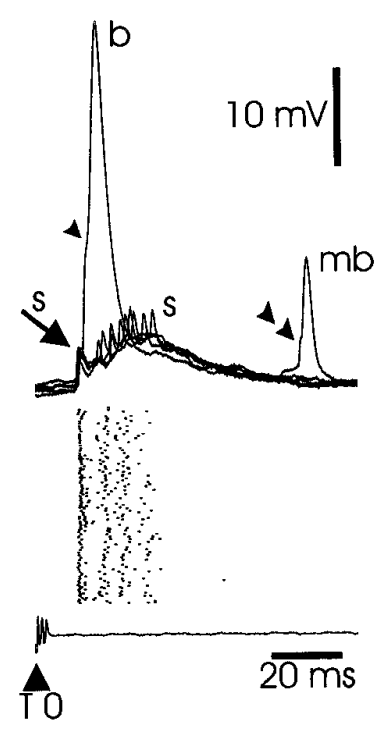

Figure 4. Medium ganglion cell: intracellular recordings. $A$, Corollary discharge responses. Top traces, Superimposed intracellular recordings of corollary discharge responses consisting of a compound EPSP giving rise to a fixed latency small spike $(s)$, followed by a burst of less strictly timed small spikes. A large broad spike $(b)$ with an inflection on the rising phase (arrowhead) is evoked on one sweep. A medium broad spike $(\mathrm{mb})$ with an amplitude corresponding to that of the inflection on the broad spike also occurs on one sweep. Raster display, Firing pattern of successive corollary discharge responses. Each line of the raster is triggered by the electric organ command signal. Each point in the raster shows the occurrence of a spike. Most spikes are small narrow spikes, but some medium and large broad spikes are also included in the raster. Bottom trace, Electric organ command signal. $T 0$, Time 0 , temporal reference point used in describing results. The recorded amplitude of the command signal varied between 100 and $200 \mu \mathrm{V}$ in different fish. The exact amplitude of this signal is not indicated in this or subsequent figures. $B$, Responses to depolarizing intracellular current pulse. Pulse of $0.3 \mathrm{nA}$ evokes small, medium, and broad spikes.

discharge (Fig. $5 A$, bottom trace) in comparison to the electrosensory IPSPs in large ganglion cells (see below). IPSPs could be evoked by near-threshold stimuli within small skin regions of a few square millimeters in area. Stimulation outside this inhibitory receptive field did not have clear effects in these cells, in contrast to the opponent-surround effects of such stimulation that were observed in the large ganglion and large fusiform cells (see below).

The effect of the electrosensory IPSP was enhanced when the electrosensory stimulus was linked to the electric organ corollary discharge by giving the stimulus at the time of the EOD, i.e., 3-5 msec after the command signal when reafferent input would normally occur in the discharging fish. This enhancement of the inhibitory effect is illustrated in Figure $5 A$, which shows the effect of the motor command $(C)$, the effect of the motor command plus an electrosensory stimulus at the time of the EOD $(C+E S)$, and the computed subtractive effect of the electrosensory stimulus $[E S$ paired $(C+E S)-C]$. Note that the computed subtractive effect of the electrosensory stimulus when given at the time of the EOD is much larger than the IPSP evoked by the same electrosensory stimulus given at a long delay of $200 \mathrm{msec}$ after the command signal (ES independent). Some of the observed enhancement could be attributable to simple shunting of the excitatory current responsible for the EPSP by the electrosensory IPSP, but some of
A
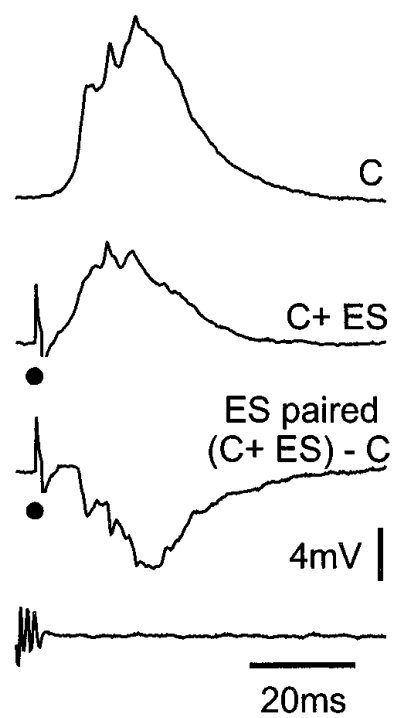

ES paired

B
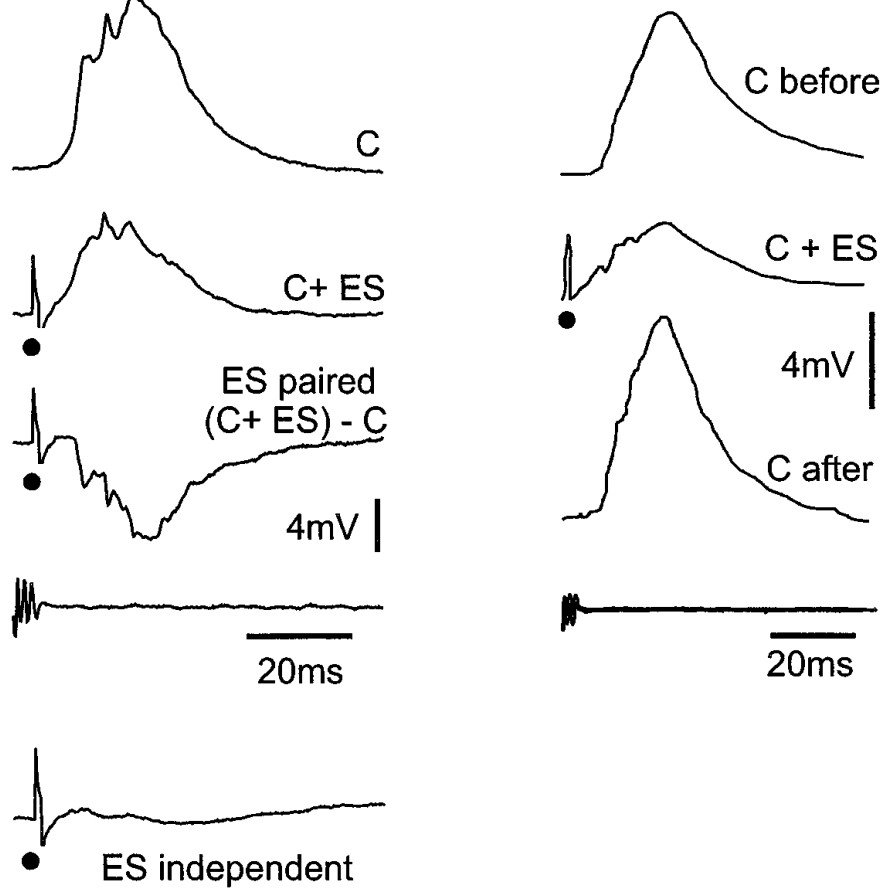

Figure 5. Medium ganglion cell: interactions between corollary discharge and electrosensory responses. $A$, Corollary discharge enhancement of inhibition by electrosensory stimulus. $C$, Postsynaptic response to corollary discharge alone; $C+E S$, response to corollary discharge plus electrosensory stimulus given at 4 msec delay; $(C+E S)-C$, computed response to ES when locked to corollary discharge, calculated by subtracting the top trace from the second trace $(C+E S)$; ES independent, response to ES given independently of corollary discharge. The IPSP is quite shallow and has a latency of $\sim 10$ msec. $B$, Corollary discharge plasticity after pairing with electrosensory stimulus. Same cell as that shown in $A$. C before, Response to corollary discharge before pairing; $C+$ $E S$, response to corollary discharge during pairing. $C$ after, Response to corollary discharge after 4 min of pairing. Note the increase in EPSP size. All traces in $A$ and $B$ are averages of 10 responses. indicates electrosensory stimulus in this and subsequent figures.

the enhancement could also be attributable to excitatory convergence of corollary discharge and primary afferent inputs onto interneurons that are responsible for the electrosensory inhibition of medium ganglion cells. The latter mechanism is clearly the best explanation for the facilitation of electrosensory responses that are observed in large ganglion cells and large fusiform cells, as described below.

The predominantly inhibitory effect of electrosensory stimuli in these cells, the characteristic corollary discharge response of a relatively fixed spike at $11-15 \mathrm{msec}$ latency followed by a more variable burst lasting $20-40 \mathrm{msec}$, and the absence of spontaneous spike activity between corollary discharge-evoked bursts make it possible to categorize these cells as $\mathrm{I}_{2}$ cells, one of the three I-cell classes described in a previous extracellular study of ELL (Bell and Grant, 1992). Thus, the $\mathrm{I}_{2}$ cells of the previous study appear to be medium ganglion cells, i.e., GABAergic interneurons with axons that terminate locally on other medium ganglion cells and on efferent neurons.

\section{Plasticity of corollary discharge responses in medium ganglion cells}

The EPSP evoked by the corollary discharge alone was enhanced after pairing with an inhibitory electrosensory stimuli in five of 
Figure 6. Medium ganglion cell: corollary discharge plasticity after pairing with an intracellular current pulse. Each column shows a different pairing of the corollary discharge with an intracellularly evoked broad spike. The top row $(C$ before $)$ shows superimposed traces of the corollary discharge response before pairing. The middle row $(C+$ intra $)$ shows superimposed traces during the $2 \mathrm{~min}$ of pairing (at a lower gain). The bottom row ( $C$ after) shows superimposed traces after the pairing. Arrows point to IPSPs that precede the EPSPs in some traces. Left column, Broad spike before the corollary discharge EPSP during pairing. Middle column, Broad spike at the time of the corollary discharge during pairing. Right column, Broad spike after the corollary discharge EPSP during pairing. Note that the corollary discharge EPSP is enhanced during pairings in which the broad spike is evoked before or after the EPSP during pairing but is depressed when the broad spike is evoked at the time of the EPSP during pairing. In the right column, the pairing-induced increase in the peak of the EPSP is less obvious than the general increase in size and duration of the EPSP. Note the hyperpolarization late in the after-pairing sweeps of the right column, presumably attributable to previous pairing with the broad spike at this delay. The vertical calibration bar at the right of the middle row is for the middle row only. The vertical calibration bar at the right of the bottom row is for both the top and bottom rows.

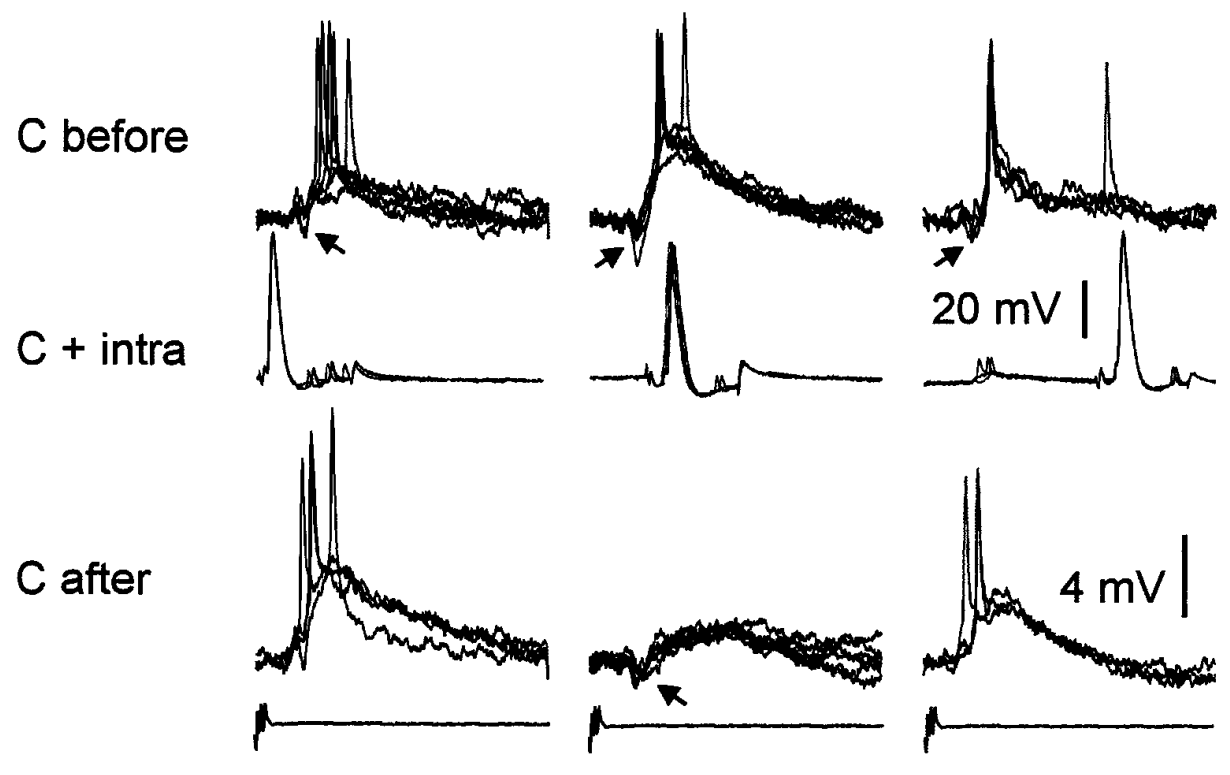

$40 \mathrm{~ms}$ the seven medium ganglion cells tested (Fig. $5 B$ ). The maximal enhancement occurred after 2-4 min of pairing, and the enhancement decayed with a similar time course after the end of the pairing. Similar enhancement of corollary discharge responses of $\mathrm{I}_{2}$ cells after pairing with an inhibitory sensory stimulus was observed in the previous extracellular study.

Corollary discharge plasticity was also observed after pairing with depolarizing intracellular current pulses, strongly suggesting that plastic change can take place at synapses between fibers that convey corollary discharge signals and the recorded cells, at least after pairing with depolarizing pulses. Two to four minutes of pairing the corollary discharge-evoked EPSP with a depolarizing intracellular current pulse that evoked a broad spike coincident with the EPSP resulted in depression of the corollary dischargeevoked EPSP (Fig. 6, middle column). This effect was observed in seven of the nine medium ganglion cells in which it was tested. Pairings at other delays in which the intracellular current pulse evoked a broad spike either just before the EPSP (Fig. 6, left column) or just after the EPSP (Fig. 6, right column) resulted in the EPSP becoming larger after the pairing. Such increases with pairing at delays other than coincidence were observed in four cells. Delivering the broad spike at random times with respect to the corollary discharge did not result in any plastic change. Pairings with hyperpolarizing current pulses, which might be expected to simulate the pairings with inhibitory sensory stimuli, were not effective (see Discussion). Some of the cells in this study were included in a previous study of plasticity in cells with broad spikes, i.e., cells that are now known to be medium ganglion cells, in the ampullary and mormyromast regions of ELL (Bell et al., 1993). The previous study was concerned with corollary discharge plasticity after pairing with intracellular current pulses and contains additional information about these experiments.

\section{Large ganglion cells}

Six cells of this type were identified morphologically after being studied physiologically (Fig. 3, middle column). These are efferent cells with a relatively large soma in the deeper part of the ganglion layer, a relatively small number of apical dendrites (in comparison to medium ganglion cells) extending throughout the molecular layer, and several short primary basilar dendrites extending from the bottom of the soma into the plexiform layer but no further. Unbranched axons projecting into the deep fiber layer were observed in three of the cells (for a more complete description of these cells, see Grant et al., 1996). An additional 19 cells with similar physiological properties were studied physiologically but were not morphologically identified. Recorded membrane potentials of the 25 cells of this type ranged from -72 to $-55 \mathrm{mV}$ (mean, $-62.2 \mathrm{mV}$; SEM, $1.0 \mathrm{mV}$ ).

In contrast to the medium ganglion cells, these large ganglion cells showed only a single type of spike, a large narrow spike that was $20-55 \mathrm{mV}$ in amplitude (mean, 35.7; SEM, $2.2 \mathrm{mV} ; n=25$ ) and 1-2 msec in duration (mean, $1.3 \mathrm{msec}$; SEM, $0.1 \mathrm{msec} ; n=$ 25 ) with a pronounced after-hyperpolarization (Figs. 7D, 8B). These cells often showed spontaneous spike activity that was not tightly locked to the command signal, again in contrast to the medium ganglion cells. The spikes could also be evoked antidromically from the mesencephalon in two of the six cells tested, showing that they are efferent projection neurons.

\section{Corollary discharge responses of large ganglion cells}

The corollary discharge had variable effects in cells of this type. The most common response (11/27 cells) was a complex of low amplitude "ripples" in which the excitatory and inhibitory effects of the corollary discharge appeared to be almost balanced so that the response was essentially flat at the resting membrane potential (Fig. $7 A, C$, top traces). Injection of hyperpolarizing current into 
A

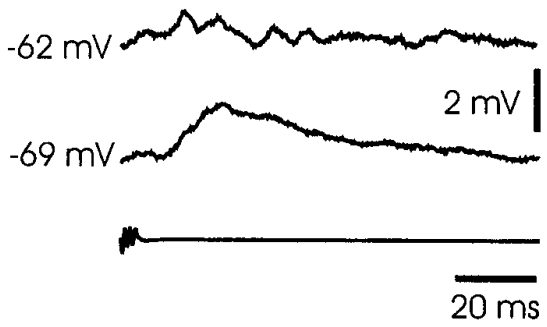

B

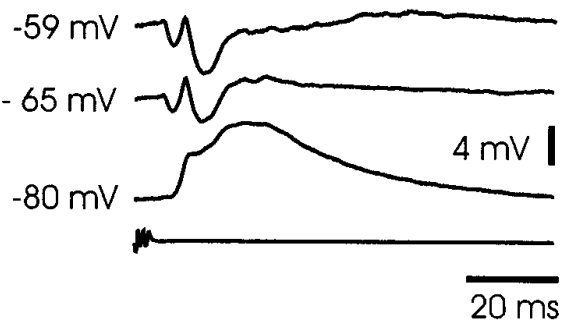

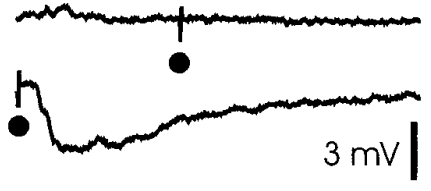

r
C

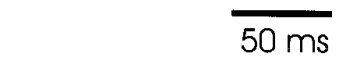

receptive field center $(-)$
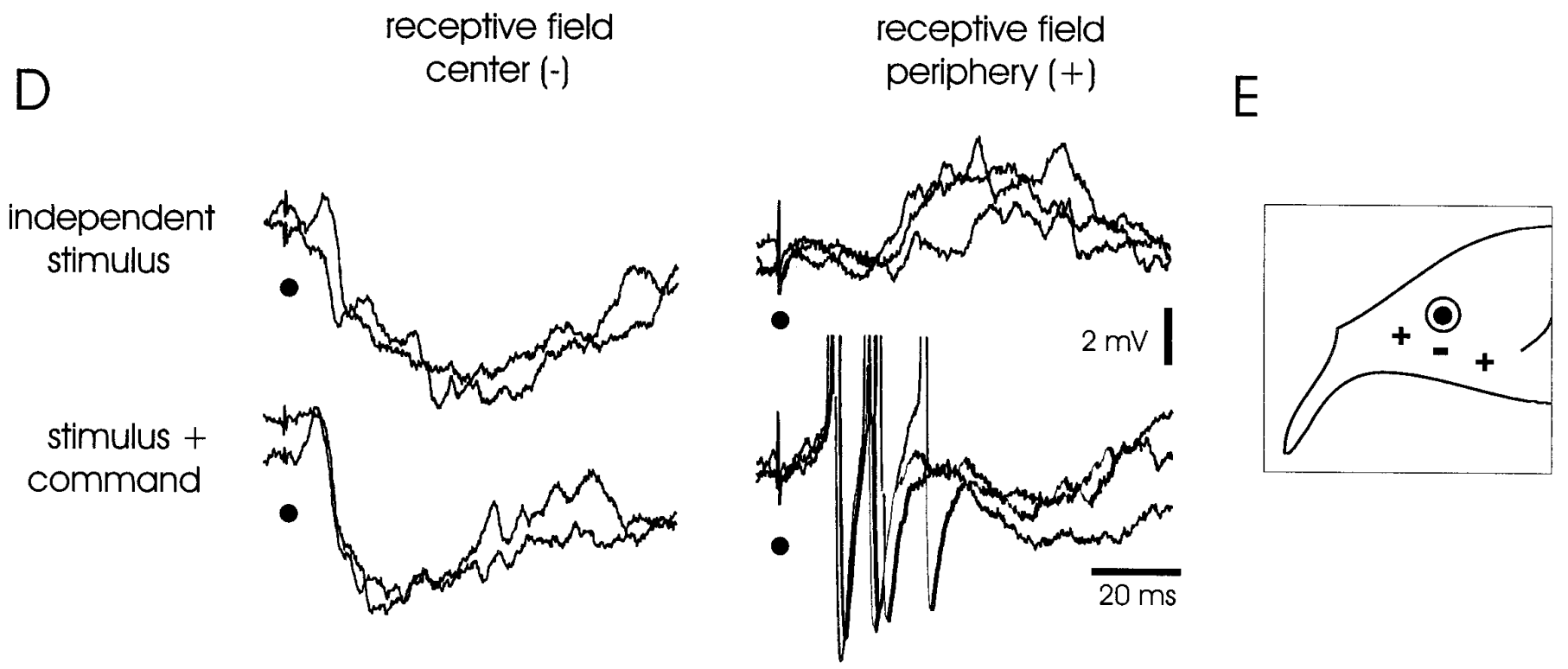

Figure 7. Large ganglion cells: corollary discharge and electrosensory responses. A, Cell with minimal corollary discharge response. Top trace, Response at resting membrane potential of $-62 \mathrm{mV}$. Middle trace, Response with cell hyperpolarized to $-69 \mathrm{mV}$. Note synaptic potential. Bottom trace, Command signal. $B$, Cell with pronounced corollary discharge response. Top trace, Response at resting membrane potential of -59 mV, showing IPSP-EPSP-IPSP sequence. Second from top trace, Response with cell hyperpolarized to $-65 \mathrm{mV}$. Third from top trace, Response with cell hyperpolarized to $-80 \mathrm{mV}$. Note the inversion of the IPSPs. Bottom trace, Command signal. $C$, Corollary discharge enhancement of inhibitory response to electrosensory stimulus. Top trace, Cell with minimal corollary discharge response. Electrosensory stimulus given at a long delay after the command does not evoke a visible response. Middle trace, The same electrosensory stimulus evokes a large IPSP when given at a short delay. Bottom trace, Command signal. D, Responses to electrosensory stimuli in center and periphery of receptive field with enhancement by corollary discharge (superimposed traces). Left traces, Electrosensory stimulus in center of receptive field evokes an IPSP. Right traces, Electrosensory stimulus in periphery evokes an EPSP. Top row, Stimulus given independent of command. Bottom row, Stimulus given at short delay after command. Note that both IPSPs and EPSPs are enhanced when stimulus is locked to command. $E$, Drawing of the head of a fish showing location of points on the skin where electrosensory stimuli cause excitation and inhibition for a cell like that shown in $D$ (-, inhibition; +, excitation).

these cells revealed the synaptic response to the corollary discharge more clearly by increasing the size of EPSPs and reducing the size of IPSPs (Fig. 7A, middle trace), showing that the flatness of the response at resting membrane potential was attributable to a balance of EPSPs and IPSPs. The next most common corollary discharge response (8/27 cells) was an IPSP-EPSP-IPSP sequence in which the first IPSP occurred at a latency of $\sim 7 \mathrm{msec}$ after the command and the second IPSP at a latency of $\sim 12 \mathrm{msec}$ (Fig. 7B). This sequence of synaptic potentials was sometimes followed by a final long-lasting EPSP (Fig. 9A). The corollary discharge-driven IPSPs of these cells could be inverted easily by passing hyperpolarizing current (Fig. 7B), suggesting that the inhibitory synaptic terminals are close to the presumed somatic recording site. Six of the 27 cells showed only an IPSP that began at $7 \mathrm{msec}$ in some cells and at $12 \mathrm{msec}$ in other cells. Finally, 2 of the 27 cells showed only a low amplitude EPSP.

\section{Electrosensory responses of large ganglion cells}

The lowest threshold response to electrosensory stimulation in all of these cells was an IPSP (Fig. 7D, left traces). All-or-none IPSPs could sometimes be evoked by low-intensity stimulation, reflecting the excitation of a single primary afferent or interneuron. As stimulus intensity was increased, the latency of the IPSP decreased, and the amplitude and duration increased. Minimum latencies were between 3 and $7 \mathrm{msec}$, the amplitudes could be as large as $15 \mathrm{mV}$, and durations were generally $>100 \mathrm{msec}$. The electrosensory-evoked IPSPs of these large ganglion cells were thus much more prominent than those observed in medium 

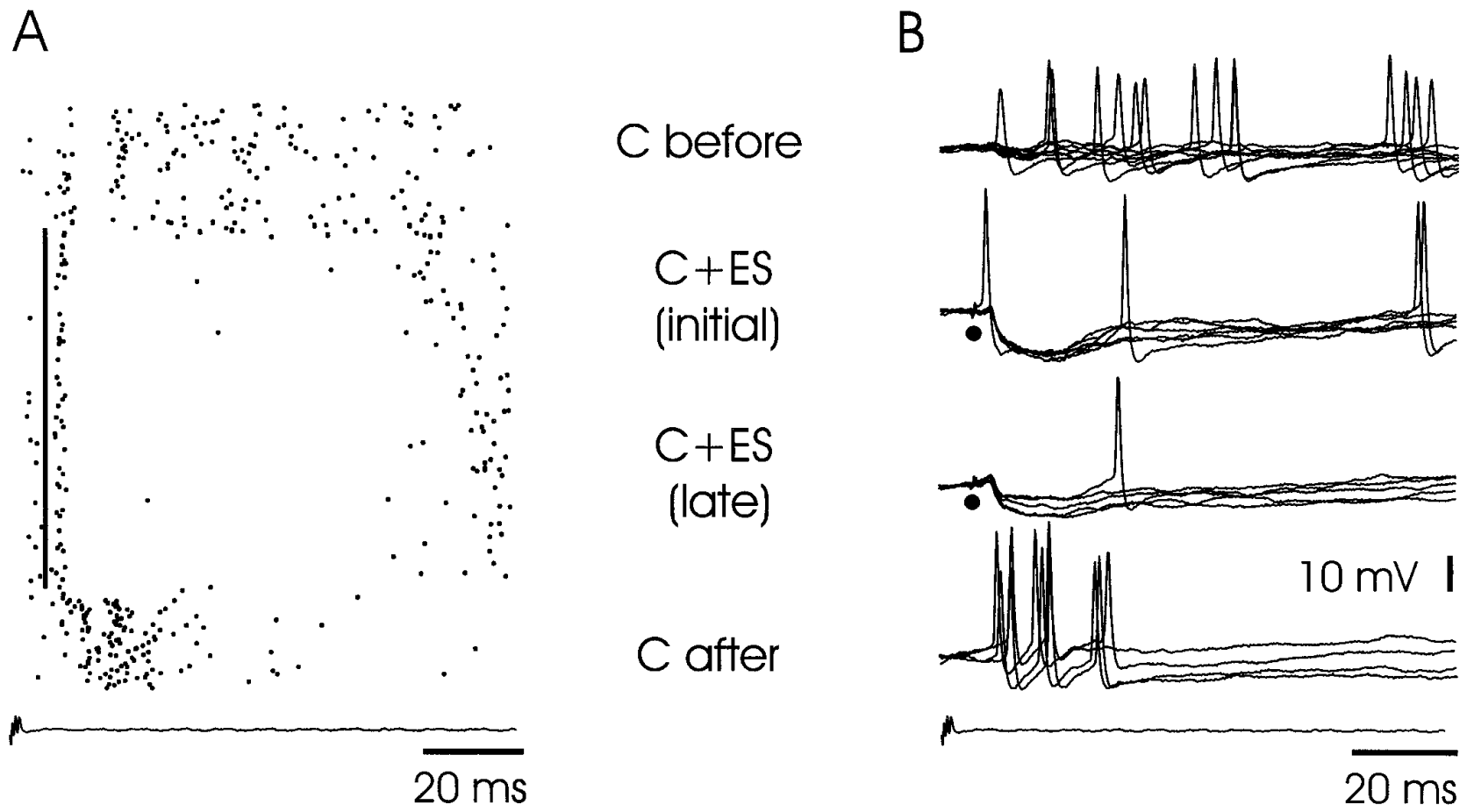

Figure 8. Large ganglion cell: plasticity of the corollary discharge response after pairing with an electrosensory stimulus. $A$, Raster display showing spike responses. C before, Corollary discharge response before pairing. $C+E S$ (initial), Responses to corollary discharge plus stimulus at start of stimulation. The vertical black line indicates the delay and presence of the stimulus. $C+E S$ (late), Responses to corollary discharge plus stimulus at the end of 2 min of pairing. $C$ after, Corollary discharge response after pairing. Note the newly developed burst. $B$, Superimposed intracellular records from same cell and epochs as in $A$. Note reduction in electrosensory IPSP after pairing.

ganglion cells. Near-threshold stimulation evoked pure IPSPs within skin regions of a few square millimeters. Higher-intensity stimulation sometimes evoked EPSPs after the initial IPSPs. Such EPSPs were probably attributable to activation of receptors outside the inhibitory center of the receptive field, because pure EPSPs could be evoked by stimulating $0.5-1.5 \mathrm{~cm}$ either rostrally or caudally to the inhibitory center (Fig. $7 D, E)$. Stimuli of the same intensity could evoke an IPSP at the center and an EPSP in the periphery. Opponent excitatory effects outside the central inhibitory region of the receptive field were clearly more prominent in the large ganglion cells than in the medium ganglion cells. Much higher currents were required to invert the electrosensoryevoked IPSPs than were required to invert the corollary discharge-evoked IPSPs in the same neurons, suggesting that the synapses responsible for the electrosensory IPSPs may be located at a greater electrotonic distance or are mediated by a different type of receptor.

As with the medium ganglion cells, the IPSPs of large ganglion cells were enhanced when the electrosensory stimulus was given near the time of the EOD. The enhancement was seen in 11 of the 12 cells tested. In most cases, the peak amplitude, the initial slope, and the time to peak of the IPSP all increased. For most of the tested cells, the peak amplitude of the tested IPSP was two to eight times greater when the IPSP was given at the time of the EOD. In two cells, a weak stimulus had no visible effect when given at a long delay but evoked a large IPSP when given at the time of the EOD (Fig. 7C). On the other hand, when stimulus intensity was high and the IPSP was close to the maximum, stimulation at the time of the EOD did not affect the amplitude but did increase the slope and reduce the time to peak of the IPSP (Fig. 7D, left traces). The EPSPs evoked by electrosensory stimuli in the periphery of the receptive field were also facilitated by the corollary discharge (Fig. 7D, right traces).

Enhancement such as that shown in Figure $7 C$ cannot be explained by interaction or summation within the recorded large ganglion cell, because there is almost no effect of the corollary discharge alone (top trace). The enhancement implies the presence of an interneuron that is responsible for the inhibition and is excited by both the corollary discharge and the primary afferent fibers.

The strong inhibitory effect of electrosensory stimuli, the complex and rather modest effect of the corollary discharge on spikes (Fig. $8 \mathrm{~A}$, top), and the occurrence of spontaneous activity unrelated to the corollary discharge (Fig. 8) made it possible to categorize these cells as $\mathrm{I}_{3}$ cells, another one of the three categories of I-cells identified in the previous extracellular study of ELL (Bell and Grant, 1992). Thus the $\mathrm{I}_{3}$ cells of the previous study appear to be large ganglion cells.

\section{Plasticity of corollary discharge responses in large ganglion cells}

The large ganglion cells of the present study, like the $\mathrm{I}_{3}$ cells of the previous study, showed clear corollary discharge plasticity after pairing with electrosensory stimuli. Such plasticity was observed in all 15 of the 15 cells tested. An example is illustrated in Figure 8, which shows the spike responses of a cell in raster form on the left and the intracellular recordings from the same cell on the right. The corollary discharge effect was first examined during an initial period without sensory input ( $C$ before). An electrosensory stimulus (indicated by a vertical black line) was then applied for 3 min just after the command signal $(C+E S)$ and then stopped abruptly. The enhanced response to the corollary dis- 
$A$

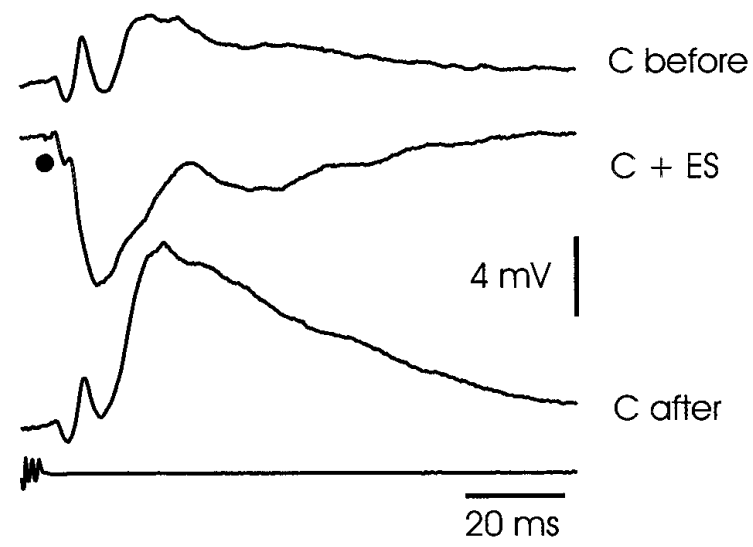

$\mathrm{B}$

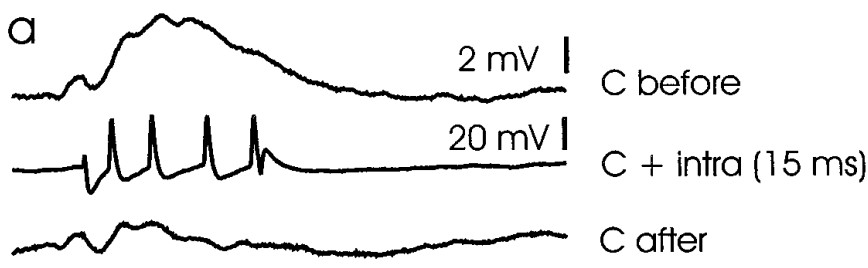

26 min recovery

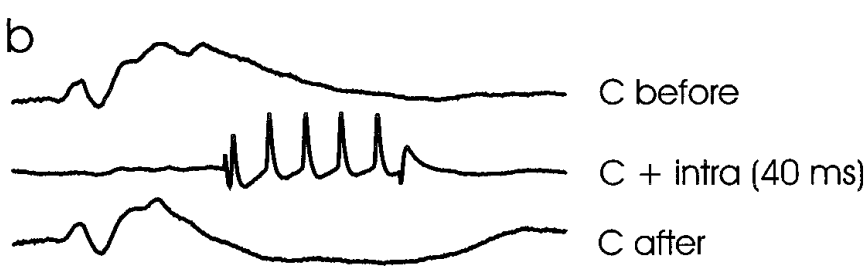

14 min recovery

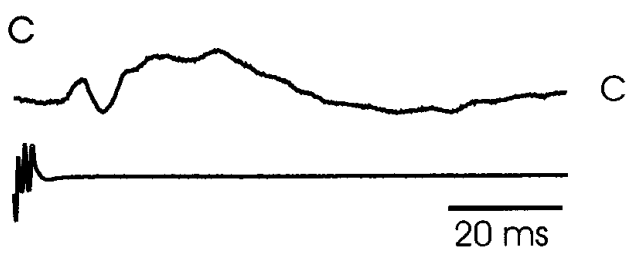

Figure 9. Large ganglion cells: corollary discharge plasticity after pairing with electrosensory stimuli and intracellular current pulses. $A$, Plasticity after pairing with an electrosensory stimulus. Traces show corollary discharge responses before pairing ( $C$ before), during pairing with an electrosensory stimulus $(C+E S)$, and after pairing $(C$ after $)$. Note that the late components are strongly affected by the pairing but the early components are not. Intracellular recordings are the averages of 10 sweeps. $B$ Plasticity after pairing with an intracellular current pulse. A different cell from that shown in $A$. $a$, Pairing with intracellular current pulse with onset at $15 \mathrm{msec}$ after the command. Traces show corollary discharge responses before pairing ( $C$ before), during pairing with intracellular charge alone after turning off the stimulus can be seen in both the raster display and the superimposed intracellular recordings (compare $C$ after with $C$ before). The effective reduction in electrosensory inhibition after $3 \mathrm{~min}$ of pairing, attributable to the increase in corollary discharge excitation, can also be seen in the intracellular recordings [compare $C+E S$ (initial) with $C+E S$ (late)]. A second example is shown in Figure $9 A$ with averaged intracellular recordings. In this case, a later component of the corollary discharge response, an EPSP with an onset at $\sim 16 \mathrm{msec}$, is greatly enhanced after 2 min of pairing with an IPSP evoked by electrosensory stimulation. Note that the early components of the corollary discharge-evoked response are not much affected by the pairing (see Discussion). As in the previous extracellular study, the plastic changes reached a maximum after 2-4 min of pairing with an electrosensory stimulus and took a similar amount of time to return to baseline after the end of pairing.

Plasticity of the corollary discharge response of these cells was also observed after pairing with depolarizing intracellular current pulses that evoked a brief train of spikes, indicating that plastic change can take place at synapses between fibers that convey corollary discharge signals and large ganglion cells, at least after pairing with depolarizing current pulses. The effect was observed in six of the nine cells tested. The effect was temporally specific and depended on the precise timing relation between the EOD motor command and the intracellular current pulse, as was also observed in previous studies of ELL cells using extracellular recording and pairing with electrosensory stimuli (Bell, 1982; Bell and Grant, 1992). This temporal specificity is illustrated by the cell shown in Figure $9 B$. The top set of three traces shows the effect of pairing with an intracellular depolarizing current pulse given at a delay of $15 \mathrm{msec}$ after the command signal. This pairing led to a marked reduction in the corollary discharge-evoked EPSP that began at $\sim 20 \mathrm{msec}$ after the command signal. The second set of three traces shows the effect of pairing with the same intracellular current pulse given at a delay of $40 \mathrm{msec}$ after the command signal. This pairing led to a reduction of only the later phases of the EPSP and the development of a long-lasting hyperpolarizing response that was roughly centered on the time of the previously paired intracellular current pulse. In this and other cells, the return to the pre-pairing corollary discharge response after pairing with intracellular current pulses took much longer than the return after pairing with electrosensory stimuli (see Discussion). Complete recovery did not seem to be present in this cell even at 26 min after the first pairing or 14 min after the second pairing. No attempt was made to assess whether postsynaptic spikes were required for these plastic changes or whether depolarization alone was sufficient. As with

$\leftarrow$

current pulse that evokes a burst of four spikes [C + intra $(15 \mathrm{~ms})]$, and after pairing for $3 \mathrm{~min}(C$ after $)$. Note depression of corollary dischargeevoked EPSP. $b$, Pairing with intracellular current pulse with onset at 40 msec after the command. Traces show corollary discharge responses before pairing ( $C$ before), during pairing with intracellular current pulse $[C+$ intra $(40 \mathrm{~ms})]$, and after pairing for $3 \mathrm{~min}(C$ after $)$. The first trace shows that the corollary discharge response has not fully recovered $26 \mathrm{~min}$ after the pairing in $a$. Note that the effect of this second pairing is delayed with respect to the effects of the first pairing, and that a long-lasting hyperpolarization developed in the response to the corollary discharge that was roughly centered on the time of the previously paired burst of spikes. $c$, Corollary discharge response $14 \mathrm{~min}$ after previous pairing. The response has almost recovered to the level observed before the second pairing in $b$. 

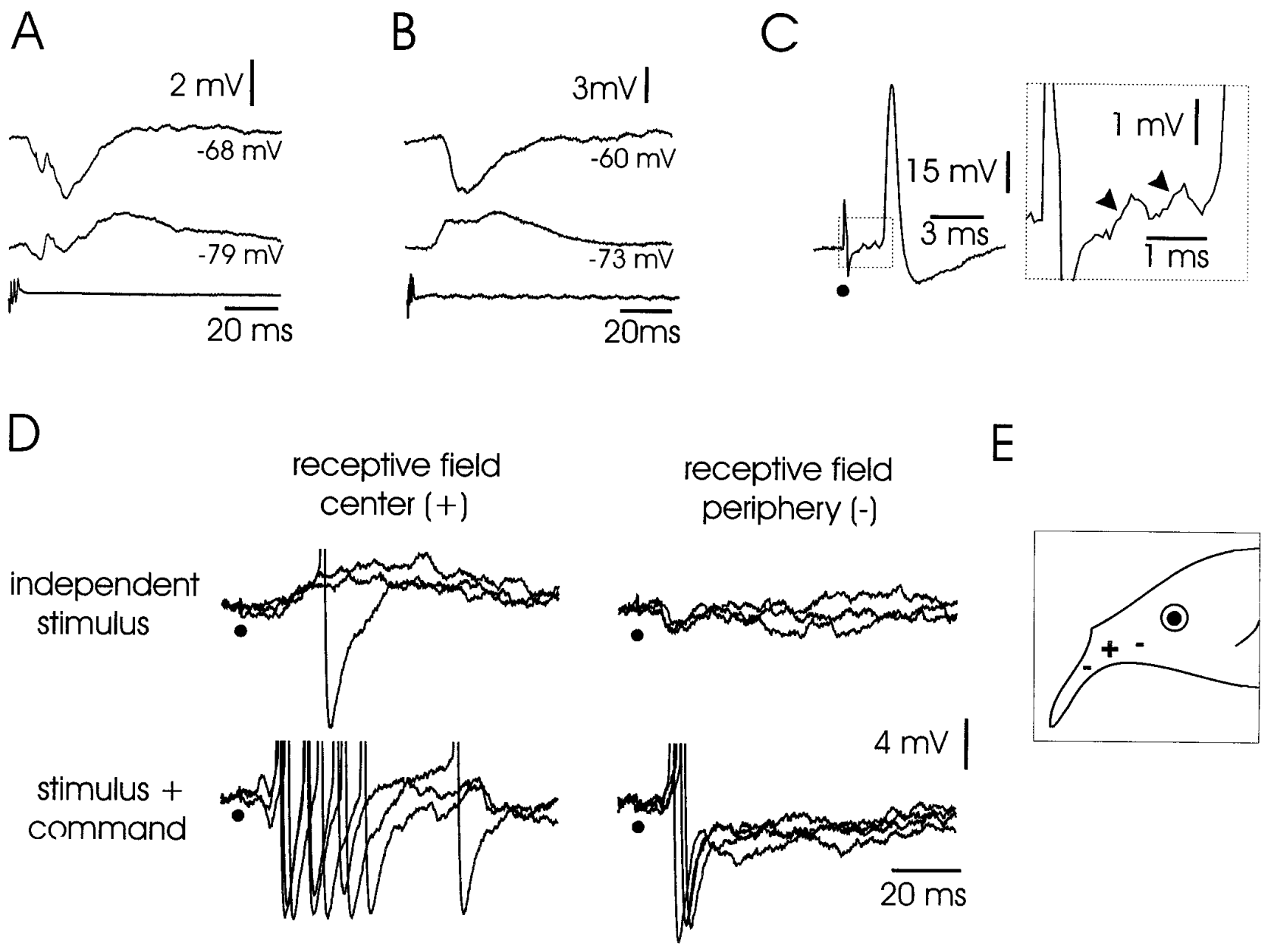

Figure 10. Large fusiform cells: corollary discharge and electrosensory responses. $A, B$, Corollary discharge-evoked IPSPs. Records from two different neurons. Each is shown at resting potential and at a hyperpolarized potential. Note that the IPSPs are inverted by hyperpolarization. $C$, Small depolarizations preceding electrosensory-evoked spike. Depolarizations indicated by arrowheads in inset (see Results). $D$, Responses to electrosensory stimuli in center and periphery of receptive field and interaction with corollary discharge (superimposed traces). Same neuron as in B. Left column, Stimuli to center of receptive field. Stimuli given independently of the command evoke small, slowly rising EPSPs, with a spike occurring on one of the EPSPs (top traces). The same stimuli given $5 \mathrm{msec}$ after the command evoke short-latency, sharply rising EPSPs, with a burst of three or four spikes on each of the EPSPs (bottom traces). Right column, Stimuli to periphery of receptive field. Stimuli given independently of the command evoke small IPSPs (top traces). Same stimuli given $5 \mathrm{msec}$ after the command evoke EPSPs and spikes. E, Drawing of the head of a fish showing location of points on the skin where electrosensory stimuli alone cause excitation and inhibition for a cell like that shown in $D(-$, inhibition; +, excitation).

medium ganglion cells, pairing with hyperpolarizing pulses did not give consistent results (see Discussion).

\section{Large fusiform cells}

Five cells of this type were morphologically identified after physiological recording. These are efferent cells with a large fusiform soma at the boundary between the plexiform and granular layer or in the superficial granular layer, apical dendrites arising from one or two primary dendrites and extending throughout the molecular layer, and several primary basilar dendrites arising from the bottom half of the cell and extending into the granular layer (for a more complete description of these cells, see Maler, 1973; Grant et al., 1996). Axons descending to the deep fiber layer could be traced in two of these cells, showing that they were efferent projection neurons. An additional 10 cells with similar physiological properties were recorded but not identified morphologically. Recorded membrane potentials of the 15 cells of this type ranged from $-75 \mathrm{mV}$ to $-55 \mathrm{mV}$.

Only large narrow spikes were observed in these cells. The spikes were 40-60 $\mathrm{mV}$ in amplitude (mean, $42.2 \mathrm{mV}$; SEM, 3.8
$\mathrm{mV} ; n=15)$ and 1-2 msec in duration (mean, $1.3 \mathrm{msec}$; SEM, 0.1 msec; $n=15$ ) and had a pronounced after-hyperpolarization (Figs. 10C,D). These spikes could be evoked antidromically from the mesencephalon in five of the eight cells tested, confirming again that they were efferent projection neurons.

\section{Corollary discharge responses of large fusiform cells}

The predominant effect of the corollary discharge in all of these cells was an IPSP. In most cases (10/17 cells) the IPSP had two phases, an initial phase beginning at $\sim 7 \mathrm{msec}$ latency and a second phase beginning at $\sim 12 \mathrm{msec}$ (Fig. 10A). In the remaining cells $(7 / 17$ cells $)$ the IPSP had a single phase that began at $\sim 12$ msec (Fig. 10B). The IPSP at 12 msec was sometimes preceded or followed by small EPSPs. The IPSPs could be readily inverted by intracellular injection of hyperpolarizing current (Fig. 10A,B).

\section{Electrosensory responses of large fusiform cells}

The lowest threshold effect of local electrosensory stimulation in all of these cells was an EPSP. Increasing stimulus intensity lead to a decrease in latency and an increase in amplitude that resulted 
in a brief burst of spikes. The decrease in latency was similar to that seen in primary mormyromast afferents with increasing intensity. The minimum latency of the EPSP ranged from 3 to 4 msec in different cells. In seven cells the minimum latency EPSPs that evoked spikes were preceded by one or two small deflections (Fig. 10C). The minimal latencies of the small deflections (1.5-2.5 msec) were the same as those observed in a previous study for action potentials in intracellular recordings from primary mormyromast afferents in ELL (Bell, 1990) and presumably reflect the arrival of spikes in mormyromast afferents. The small deflections were not field potentials, because they were not observed when the electrode was outside the cell but still within a few micrometers of the intracellular recording site. The deflections thus suggest a small amount of direct electrical coupling between primary afferents and large fusiform cells through electrical synapses or some other type of ephaptic interaction. Large fusiform cells have their basilar dendrites in the granular layer where the primary afferents terminate; however, the fact that the EPSPs giving rise to the spikes occurred at least $1.5 \mathrm{msec}$ after the first small deflection indicates that such direct electrical coupling is not of primary importance in the activation of these cells by afferent input. Such a delay is also rather long for a single synaptic delay at a chemical synapse and suggests the possibility of an interneuron between primary afferents and large fusiform cells, a conclusion that is strongly supported by the facilitatory effect of the corollary discharge on electrosensory responses (see below).

Electrosensory stimulation rostral or caudal to the central excitatory receptive field of these cells often (9/17 cells) evoked a small IPSP (Fig. 10D, top traces on right). Thus, the centersurround organization of receptive fields for both large fusiform and large ganglion cells was more prominent than that for the medium ganglion cells.

The excitatory effect of an electrosensory stimulus to the center of the receptive field was markedly enhanced when the stimulus was given just after the command signal at the time of the EOD (Fig. 10D, left traces). The traces of Figure $10 \mathrm{~A}$ were recorded from the same cell as that shown in Figure $10 D$ and show that the effect of the command alone for this cell was an IPSP. Thus the strongly facilitatory effect of the motor command was not attributable to a simple summation of a corollary discharge EPSP and the peripherally evoked EPSP in the recorded large fusiform cell. Instead, the strong facilitatory effect of the command in this cell, and in other cells like it, indicates the presence of an interneuron between the afferent input and the large fusiform cell, an interneuron that is excited by both primary afferent and corollary discharge input.

The inhibitory effect of stimulating outside the excitatory center was not enhanced by giving the stimulus just after the command signal at the time of the EOD in any of the cells in which this was tested. Instead, such coupling inverted the sign of the stimulus effect, converting it to a weak excitation (Fig. 10D, right traces). Presumably, such stimuli in the periphery of the receptive field caused a mixture of excitation and inhibition, and the facilitatory effect of the motor command on the excitatory component was larger than any facilitatory effect on the inhibitory component.

The strong excitatory effect of a local electrosensory stimulus delivered to the most sensitive point on the skin surface indicates that the large fusiform cell is an E-cell. Similar cells with a small corollary discharge-driven inhibition and strong excitation within a well localized skin region were also recorded in the previous extracellular study (Bell and Grant, 1992).

\section{Plasticity of corollary discharge responses in large fusiform cells}

Corollary discharge responses of large fusiform cells, like those of many E-cells in the previous study, showed clear plastic changes after pairing with an electrosensory stimulus. The plasticity was observed in all seven of the seven tested cells. An example is illustrated in Figure 11. The small corollary discharge-evoked IPSP present before pairing was greatly enhanced after 2-5 min of pairing with an excitatory electrosensory stimulus (Fig. 11). Corollary discharge plasticity after pairing with intracellular current pulses was not tested in any of the large ganglion cells.

\section{Additional observations}

Morphological studies have shown that there are several other types of cells in ELL in addition to medium ganglion cells, large ganglion cells, and large fusiform cells (Meek et al., 1996), and other elements were recorded with physiological properties quite different from any of these cells. These included cells with regular bursts in response to the corollary discharge, primary afferent fibers from mormyromast electroreceptors, and glial cells.

Three cells were recorded intracellularly with a very regular burst of three to seven action potentials in response to the corollary discharge (Fig. 12), with the first spike occurring at a latency of 7 to $9 \mathrm{msec}$ (several milliseconds earlier than the first spike of the medium ganglion cells). Electrosensory stimuli given at the time of the EOD inhibited the spikes of this burst in a graded fashion. The spikes of these cells were only a few millivolts in amplitude and lacked an after-hyperpolarization, suggesting that they might be axonal spikes arising at some distance from the presumed somatic recording site. The properties of these cells were the same as those of the $\mathrm{I}_{1}$ cells recorded in the previous extracellular study. None of these cells were identified morphologically.

Recordings from mormyromast afferent fibers were also obtained. These recordings show a highly stereotyped corollary discharge-driven EPSP with a latency of 6 to $8 \mathrm{msec}$ after the command signal, as described in a previous study of these afferents (Bell, 1990). The EPSP is probably attributable to synaptic input to granule cells that is observed in the afferent fiber via the electrical synapses between afferent fibers and granule cells (Bell et al., 1989). The EPSP is not affected by prolonged pairing with an electrosensory stimulus that excites the afferent, i.e., it does not show plasticity. An example of the corollary discharge EPSP in a mormyromast afferent is shown in Figure 13 [trace marked granule cell (primary afferent)].

Presumptive glial cells were also recorded. These cells had large stable membrane potentials of -85 to $-90 \mathrm{mV}$, and no action potentials could be evoked by intracellularly injected currents. The voltage responses to electrosensory stimuli and to the corollary discharge were similar but not identical to the extracellularly recorded field potentials just outside the cell. Initial components of both responses were the same, but later positive-going components beginning at $\sim 7 \mathrm{msec}$ delay were two to three times larger in the intracellular recordings than in the extracellular recordings. The larger positivities probably reflect the accumulation of potassium in the extracellular space outside the glial cells at the longer delays. Such accumulation could be attributable to action potentials or to the opening of potassium channels during inhibition.

Stimulation of the lateral lemniscus at the level of the mesencephalon evoked synaptic responses in some cells in addition to the previously described antidromically driven action potentials. Such responses were recorded in seven different cells and in- 

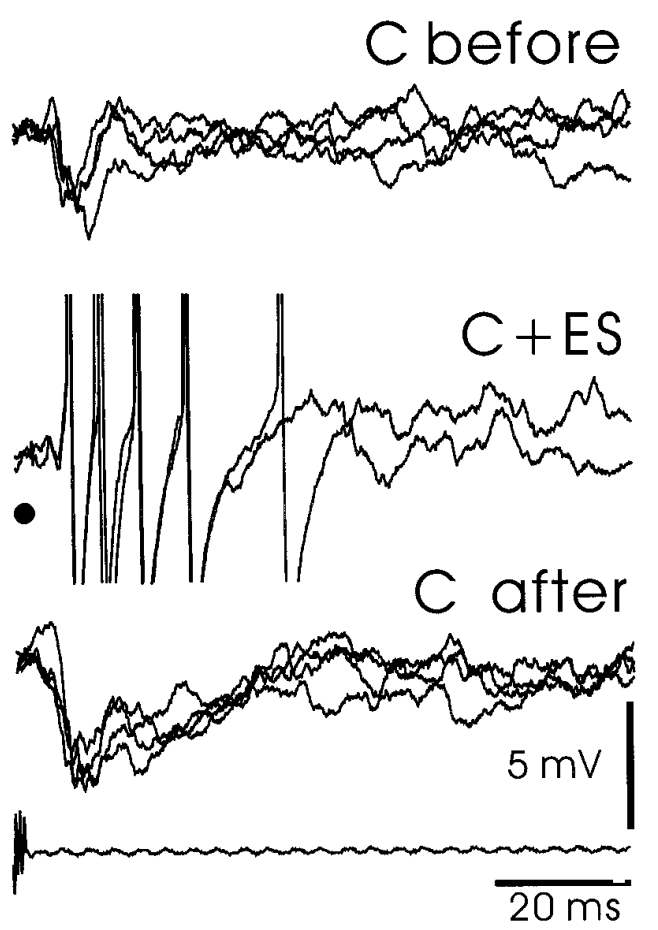

Figure 11. Large fusiform cell: corollary discharge plasticity after pairing with an electrosensory stimulus. $C$ before, Corollary discharge evokes only a small IPSP before pairing. $C+E S$, Electrosensory stimulus evokes a burst of spikes when paired with the corollary discharge. $C$ after, Corollary discharge evokes a much large IPSP after 2 min of pairing with an electrosensory stimulus.
A

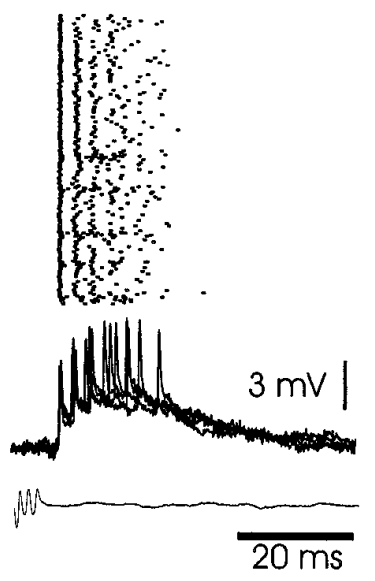

B
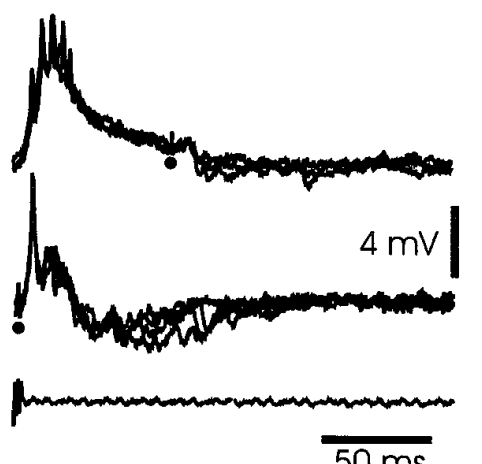

Figure 12. $\mathrm{I}_{1}$-type cell: corollary discharge and electrosensory responses. $A$, Corollary discharge responses of $\mathrm{I}_{1}$ cell shown with raster display of spikes and superimposed intracellular traces. $B$, Corollary discharge enhancement of electrosensory IPSP in $\mathrm{I}_{1}$ cell. Top traces, Electrosensory stimuli at a delay of $70 \mathrm{msec}$ after the command evoke small IPSPs. Bottom traces, The same stimuli at a delay of $3 \mathrm{msec}$ evoke much larger IPSPs that reduces the size of the corollary discharge EPSP.

cluded EPSPs, IPSPs, and EPSP-IPSP sequences. The synaptic responses are probably not attributable to local recurrent collaterals of efferent cells because no such collaterals have been observed anatomically (Grant et al., 1996). Axons of efferent cells do give off extensive collaterals to the nucleus preeminentialis, however, and the cells of preeminentialis send axons to the deep

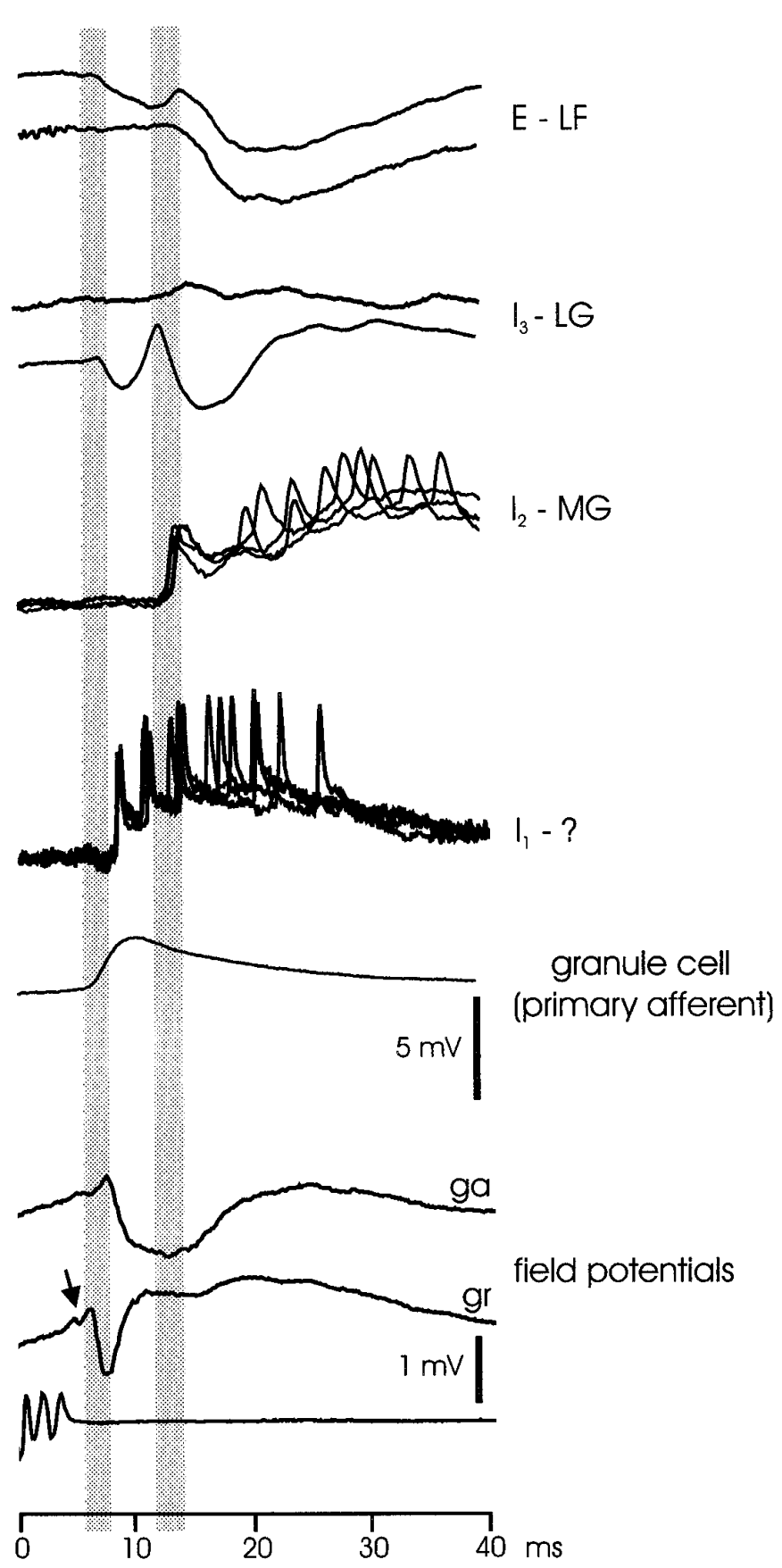

Figure 13. Summary figure showing the timing of corollary responses in ELL: intracellularly recorded cells and extracellularly recorded field potentials. $E-L F$, Corollary discharge responses of two large fusiform cells (E-cells). $I_{3}-L G$, Corollary discharge responses of two large ganglion cells $\left(\mathrm{I}_{3}\right.$ cells). $I_{2}-M G$, Corollary discharge responses of a medium ganglion cell $\left(\mathrm{I}_{2}\right.$ cell). $I_{1}$ - ?, Corollary discharge response of $\mathrm{I}_{1}$ cell with unknown morphology. granule cell (primary afferent), Corollary discharge response recorded inside primary afferent that is attributable to synaptic input to granule cells. field potentials, Corollary discharge responses shown with extracellularly recorded field potentials in ganglion $(\mathrm{ga})$ and granule ( $g r$ ) layers. Arrow points to small deflection signaling arrival of juxtalobar input at ELL. Shaded bars show division of responses into shorter and longer latency events. The gains for the first five sets of traces, which are intracellular recordings, are given by the $5 \mathrm{mV}$ vertical scale bar. The gains for the two bottom traces, which are extracellularly recorded field potentials, are given by the $1 \mathrm{mV}$ vertical scale bar. 
molecular layer of ELL (Bell et al., 1981), forming a feedback loop. The synaptic potentials evoked by stimulation of the lateral lemniscus are most likely attributable to antidromic activation of the axon collaterals to nucleus preeminentialis followed by activation of preeminentialis cells that project to ELL.

\section{DISCUSSION}

\section{General}

This study has described the physiological properties of three different types of neurons of the mormyrid ELL: the medium ganglion cell, the large ganglion cell, and the large fusiform cell. These three types of neurons are the major cells with apical dendrites that extend throughout the molecular layer and basilar dendrites that extend into the deeper cell layers. As such, they are of central importance for the integration of parallel fiber signals, with primary afferent signals to the deeper layers.

The efferent neurons, the large ganglion, and large fusiform cells are of particular interest because they convey the results of ELL integration to the next higher levels of the electrosensory system. The large ganglion cell is inhibited by electrosensory stimuli in the center of its receptive field, whereas the large fusiform cell is excited by such stimuli. Two types of efferent neurons with such opposite properties are also found in the gymnotid ELL (Saunders and Bastian, 1984) and in the retina. Local decreases in stimulus strength convey as much information as local increases in each of these different systems, and this appears to be reflected in separate efferent cells for the two directions of stimulus change.

This study showed a rather remarkable difference in the intrinsic physiology of medium ganglion cells on the one hand and the two types of efferent cells on the other. The medium ganglion cells consistently showed two types of spikes, a small narrow spike and a large broad spike, whereas the large ganglion and fusiform cells showed only a single type of large narrow spike. The same clear difference in spike types has been obtained in a recent in vitro study of the mormyrid ELL (C. Bell, V. Han, Y. Sugawara, L. Gomez Sena, and K. Grant, unpublished observations).

The cellular origins of the two types of spikes in the medium ganglion cells have not been established, but the large broad spikes probably originate from the somas or dendrites, and the small narrow spikes probably originate in the axon or initial segment but do not invade the soma and are conducted only passively to the recording site. The intracellular recordings of this study were most likely taken from the soma or dendrites rather than the axons, because the axons of medium ganglion cells are only $0.5 \mu \mathrm{M}$ in diameter (Meek et al., 1996). Thus, the relative sizes of the two types of spikes suggest that the large broad spikes originate electrotonically close to the soma, whereas the small narrow spikes originate at some electrotonic distance. The lower threshold of the small narrow spikes to intracellular current injection suggests an axonal origin for these spikes, because axon spikes are known to have a lower threshold than somatic or dendritic spikes in other central cells (Stuart and Häusser, 1994; Stuart and Sakmann, 1994).

\section{Circuitry of ELL}

The present results imply certain features of ELL circuitry. One such feature is the presence of interneurons between primary afferent input and the types of neurons examined here. This is obviously true for the medium and large ganglion cells that are inhibited by electrosensory stimuli, because primary afferent fibers are excitatory (Bell, 1990) and an inhibitory interneuron is required to mediate such inhibition. The need for an interneuron between primary afferents and large fusiform cells, based on strong facilitation by the corollary discharge, was unexpected. Primary afferents terminate in the granular layer where the somas and basilar dendrites of large fusiform cells are located, and the efferent E-cell in the gymnotid ELL appears to be directly excited by primary afferents (Maler et al., 1981; Saunders and Bastian, 1984). The conclusion regarding the lack of primary afferent synapses on large fusiform cells is supported, however, by an anatomical study of the mormyrid ELL (Grant et al., 1996). Electrosensory responses of all three neurons were strongly enhanced by the corollary discharge, indicating that the interneurons that mediate these responses must be excited by the corollary discharge, and such excitation has been demonstrated for granule cells on which primary afferents terminate with electrical synapses (Bell, 1990).

Golgi studies show two different types of medium ganglion cells (Meek et al., 1996), one with basilar dendrites restricted to the plexiform layer like the large ganglion cell and another with basilar dendrites in the granular layer like the large fusiform cell (Fig. 2, $M G_{1}$ and $M G_{2}$, respectively). These comparisons suggest that the $\mathrm{MG}_{1}$ cells might be I-cells and the $\mathrm{MG}_{2}$ cells might be E-cells, although our study does not confirm this. A large majority of the MG cells in this study had a predominantly inhibitory response to electrosensory stimulation. A few MG cells were mainly excited by electrosensory stimuli, but it is not known whether this was because such cells represent a separate class of cells or because of a failure to locate the inhibitory center of the receptive fields of these cells.

\section{Corollary discharge responses}

The electric organ corollary discharge has various effects on ELL cells that extend from $\sim 5 \mathrm{msec}$ to $\sim 100 \mathrm{msec}$ after the EOD motor command. The corollary discharge responses of some elements such as the granule cells and $\mathrm{I}_{1}$ cells are stereotyped EPSPs, whereas the responses of other elements are a variable mixture of excitation and inhibition. Figure 13 shows the relative timing of intracellularly recorded responses from a number of different elements, as well as extracellular field potentials recorded in the ganglion and granular layers (the initial ramp-like positivity in the field potentials is attributable to volume conduction from EGp and does not reflect the excitation of ELL cells). The figure shows that many of the EPSP and IPSP onsets cluster around two time periods, $6-8 \mathrm{msec}$ and $11-13 \mathrm{msec}$ after the command, as indicated by the vertical gray bars. Juxtalobar fibers discharge with a single spike at $\sim 5 \mathrm{msec}$ after the command, and the events within the first time period are probably driven by fibers from this nucleus, either directly or within a few synaptic delays (the arrival of this input at ELL is indicated by a small negative wave indicated by an arrow in the next to last trace of Fig. 13) (Bell and von der Emde, 1995). Events beginning within the second time period, and later, probably represent a combination of responses to ELL cell activity initiated during the first period together with corollary discharge inputs from other sources such as EGp (Bell et al., 1992) and nucleus preeminentialis (von der Emde and Bell, 1996).

The corollary discharge responses of most large ganglion and large fusiform cells were quite small and largely inhibitory in the absence of previous pairing with an electrosensory stimulus, in comparison with the strong excitatory responses of interneurons such as the medium ganglion cell, the morphologically unidentified $I_{1}$ cells, or granule cells (the last cell type revealed by 
recordings from primary afferent fibers, as described above). In several efferent cells, the absence of a strong corollary discharge response at the resting membrane potential was shown to be attributable to a balance between excitatory and inhibitory synaptic inputs to the cell. Thus, the strong excitatory corollary discharge responses in the initial stages of processing are not present at the output stage. This suggests that strong excitatory corollary discharge responses found at subsequent stages of the electrosensory system, such as those in the preeminential nucleus (von der Emde and Bell, 1996), are not caused by input from ELL but by an independent corollary discharge input.

\section{Plasticity}

Some corollary discharge responses are plastic and some are not. Thus the corollary discharge-driven EPSPs of granule cells are not modified at all by long periods of pairing with an electrosensory stimulus (Bell, 1990). Similarly the $\mathrm{I}_{1}$ type of cell shows a highly stereotyped burst that is not modified after pairing with an electrosensory stimulus that silences the burst (Bell and Grant, 1992). Even within a single cell, some components of the corollary response are modified after pairing but other components are not. For example, the initial components of the corollary discharge responses of large ganglion cells are only minimally affected by pairing, whereas the later components are markedly affected (compare $C$ before and $C$ after in Fig. $9 A$ ). Similarly, the initial EPSP and spike of the corollary discharge response of medium ganglion cells are only minimally affected by pairing, whereas the later EPSP and spike burst are greatly affected, as was also noted in the previous extracellular study of $\mathrm{I}_{2}$ cells (Bell and Grant, 1992). Thus, the earliest components, which are probably driven most strongly by the juxtalobar nucleus, show little plasticity in comparison with the later components beginning at $\sim 14$ msec.

The later more plastic responses are probably driven predominantly by parallel fiber inputs from EGp and by direct inputs to the deep molecular layer from nucleus preeminentialis. The exact timing of parallel fiber inputs has not been determined, but the timing of corollary discharge inputs to EGp is distributed over a wide temporal window from 0 to $\sim 80 \mathrm{msec}$ after the command. Similarly, all of the corollary discharge responses of cells in nucleus preeminentialis have latencies longer than $10 \mathrm{msec}$ (von der Emde and Bell, 1996). Furthermore, recent findings support the conclusion that responses of ELL cells to these two inputs are plastic. Plasticity at parallel fiber synapses has been demonstrated in a recent in vitro study of the mormyrid ELL (Bell et al., 1997a,b), and evidence for such plasticity has been obtained in the gymnotid ELL (J. Bastian, personal communication) and the elasmobranch dorsal octavolateral nucleus (Bodznick et al., 1996). Responses of ELL cells to input from nucleus preeminentialis has also been shown to be plastic in gymnotid fish (Bastian, 1996).

Corollary discharge plasticity was observed in medium ganglion and large ganglion cells after pairing with electrosensory stimuli that evoked hyperpolarizations (IPSPs), but with intracellular current pulses plasticity was observed only after pairing with depolarizing current pulses and not after pairing with hyperpolarizing current pulses, unless those pulses evoked a rebound postsynaptic spike. Depolarizations occur naturally in these cells after stimulation of the surround region of the receptive field or when the cell is disinhibited after reduction of electrosensory input to the center of the field, but the lack of effect of pairing with hyperpolarizing pulses that do not evoke rebound spikes is puzzling. In other cerebellum-like structures, plasticity of responses to descending input appears to occur after pairing with such pulses (Bastian, 1996) (D. Bodznick, personal communication). Changes in the pairing protocol might yield positive results with hyperpolarizing current pulses, but it is also possible that cells in the mormyrid ELL show plasticity only when a postsynaptic spike occurs. Reciprocally inhibitory circuitry between E- and I-cells would still allow for the observed effects of pairing with purely inhibitory electrosensory stimuli.

Propagation of a spike into the apical dendrites of the molecular layer may be important for synaptic plasticity. Plasticity in neocortical cells (Markram et al., 1997) and some types of plasticity in the hippocampus (Magee and Johnston, 1997) depend on the coincidence of EPSPs with apical dendritic spikes during pairing. A similar process may occur in the ELL of mormyrid fish and in the cerebellum-like structures of other fish. Propagated spikes have been demonstrated in the molecular layer dendrites of ELL cells in gymnotid fish (Turner et al., 1994), and evidence for such spikes has been obtained in in vitro studies of the mormyrid ELL (C. Bell, V. Han, Y. Sugawara, L. Gomez Sena, and K. Grant, unpublished observations). In vitro work in the mormyrid ELL has also shown that plasticity of the parallel fiber-evoked EPSP is dependent on the relative timing of EPSP and the postsynaptic broad spike, suggesting that the broad spike is necessary for the plasticity. Evidence for the importance of the broad spike in the corollary discharge plasticity of cells showing such spikes was also obtained in a previous in vivo study (Bell et al., 1993). Propagation of a spike into the apical dendrites would provide a mechanism of communication between the basilar parts of the cells where sensory inputs terminate and the apical dendrites where the parallel fibers terminate, allowing sensory and parallel fiber inputs to interact.

In summary, this study has determined the corollary discharge responses, the electrosensory responses, and some of the intrinsic cellular properties of three important and morphologically distinct cell types in the mormyrid ELL. Functional aspects of the circuitry have been established as well as some of the properties of corollary discharge plasticity in the different cell types.

\section{REFERENCES}

Bastian J (1986) Gain control in the electrosensory system mediated by descending inputs to the electrosensory lateral line lobe. J Neurosci 6:553-562.

Bastian J (1995) Pyramidal-cell plasticity in weakly electric fish: a mechanism for attenuating responses to reafferent electrosensory inputs. J Comp Physiol 176:63-78.

Bastian J (1996) Plasticity in an electrosensory system. II. Postsynaptic events associated with a dynamic sensory filter. J Neurophysiol 76: 2497-2507.

Bell CC (1981) An efference copy modified by reafferent input. Science 214:450-453.

Bell CC (1982) Properties of a modifiable efference copy in electric fish. J Neurophysiol 47:1043-1056.

Bell CC (1989) Sensory coding and corollary discharge effects in mormyrid electric fish. J Exp Biol 146:229-253.

Bell CC (1990) Mormyromast electroreceptor organs and their afferents in mormyrid electric fish. II. Intra-axonal recordings show initial stages of central processing. J Neurophysiol 63:303-318.

Bell CC, Grant K (1992) Corollary discharge effects and sensory processing in the mormyromast regions of the mormyrid electrosensory lobe. II. Cell types and corollary discharge plasticity. J Neurophysiol 68:859-875.

Bell CC, von der Emde G (1995) Electric organ corollary discharge pathways in mormyrid fish. II. The medial juxtalobar nucleus. J Comp Physiol [A] 177:463-479.

Bell CC, Finger TE, Russell CJ (1981) Central connections of the posterior lateral line lobe in mormyrid fish. Exp Brain Res 42:9-22.

Bell CC, Zakon H, Finger TE (1989) Mormyromast electroreceptor 
organs and their afferent fibers in mormyrid fish. I. Morphology. J Comp Neurol 286:391-407.

Bell CC, Grant K, Serrier J (1992) Corollary discharge effects and sensory processing in the mormyrid electrosensory lobe. I. Field potentials and cellular activity in associated structures. J Neurophysiol 68: 843-858.

Bell CC, Caputi A, Grant K, Serrier J (1993) Storage of a sensory pattern by anti-Hebbian synaptic plasticity in an electric fish. Proc Nat Acad Sci USA 90:4650-4654.

Bell CC, Han V, Sugawara Y, Grant K (1997a) Synaptic plasticity in a cerebellum-like structure depends on temporal order. Nature 387: $278-281$.

Bell CC, Bodznick D, Montgomery J, Bastian J (1997b) The generation and subtraction of sensory expectations within cerebellum-like structures. Brain Behav Evol 50[Suppl 1]:17-31.

Bodznick D, Carey MR, Larner BW (1996) Locating the site of adaptive reafference suppression: evidence for a role of parallel fibers. Soc Neurosci Abstr 22:449.

Grant K, Meek J, Sugawara Y, Veron M, Denizot JP, Hafmans J, Serrier J, Szabo T (1996) Projection neurons of the mormyrid electrosensory lateral line lobe: morphology, immunocytochemistry and synaptology. J Comp Neurol 375:18-42.

Hanker JS, Yates PE, Metz CB, Rustioni A (1977) A new specific, sensitive, and non-carcinogenic reagent for the demonstration of HRP. Histochem J 9:789-792.

Maler L (1973) The posterior lateral line lobe of a mormyrid fish: a Golgi study. J Comp Neurol 152:281-299.

Maler L, Sas EKB, Rogers J (1981) The cytology of the posterior lateral line lobe of high frequency weakly electric fish (Gymnotidae): dendritic differentiation and synaptic specificity in a simple cortex. J Comp Neurol 195:87-140.

Magee J, Johnston D (1997) A synaptically controlled, associative signal for Hebbian plasticity in hippocampal neurons. Science 275:209-213.

Markram H, Lubke J, Frotscher M, Sakmann B (1997) Regulation of synaptic efficacy by coincidence of postsynaptic APs and EPSPs. Science 275:213-215.

Meek J (1993) Structural organization of the mormyrid electrosensory lateral line lobe. J Comp Physiol [A] 173:675-677.

Meek J, Grant K, Sugawara S, Hafmans TGM, Veron M, Denizot JP (1996) Interneurons of the ganglionic layer in the mormyrid electrosensory lateral line lobe: morphology, immunocytochemistry, and synaptology. J Comp Neurol 375:43-65.

Montgomery JC, Bodznick D (1994) An adaptive filter that cancels self-induced noise in the electrosensory and lateral line mechanosensory systems of fish. Neurosci Lett 174:145-148.

Montgomery JC, Coombs S, Conley RA, Bodznick D (1995) Hindbrain sensory processing in lateral line, electrosensory, and auditory systems: a comparative overview of anatomical and functional similarities. Auditory Neurosci 1:207-231.

Saunders J, Bastian J (1984) The physiology and morphology of two types of electrosensory neurons in the weakly electric fish Apteronotus leptorhynchus. J Comp Physiol [A] 154:199-209.

Stuart G, Häusser M (1994) Initiation and spread of sodium action potentials in cerebellar Purkinje cells. Neuron 13:703-712.

Stuart GJ, Sakmann B (1994) Active propagation of somatic action potentials into neocortical pyramidal cell dendrites. Nature 367:69-72.

Turner RW, Maler L, Deerinck T, Levinson SR, Ellisman MH (1994) TTX-sensitive dendritic sodium channels underlie oscillatory discharge in a vertebrate sensory neuron. J Neurosci 14:6453-6471.

von der Emde G, Bell C (1996) Nucleus preeminentialis of mormyrid fish, a center for recurrent electrosensory feedback. I. electrosensory and corollary discharge responses. J Neurophysiol 76:1581-1596.

von Holst E, Mittelstaedt H (1950) Das Reafferenzprinzip. Naturwissenschaften 37:464-476.

Zipser B, Bennett MVL (1976) Interaction of electrosensory and electromotor signals in the lateral line lobe of a mormyrid fish. J Neurophysiol 39:713-721. 